Amer. J. Bot. 58(8): 758-784. 1971.

\title{
ON THE ANATOMY AND MORPHOLOGY OF LATERAL BRANCH SYSTEMS OF ARCHAEOPTERIS ${ }^{1}$
}

\author{
Charles B. Beck \\ Department of Botany, University of Michigan, Ann Arbor
}

DEDICATED TO PROFESSOR CHESTER A. ARNOLD IN THE YEAR OF HIS OFFICIAL RETIREMENT AS PROFESSOR OF BOTANY AT THE UNIVERSITY OF MICHIGAN, IN HONOR OF HIS DISTINGUISHED SERVICE TO THE FIELDS OF MORPHOLOGY AND PALEOBOTANY.

\section{A $\quad$ B $\quad S \quad T \quad R \quad A \quad C \quad T$}

A large collection of specimens, consisting primarily of Archaeopieris macilenta, forms the basis for an anatomical and morphological study of the lateral branch systems. Emphasis is placed on the main axes of the branch systems, which are found to be characterized by a variable number of orthostichies of lateral appendages, ranging from 7 to probabiy 11. The number of orthostichies seems to correspond to the number of ribs of the stele. There may be an equal number of rows of leaves on either side of the plane in which the two rows of lateral branches lie, or one side may have one or two more leaf orthostichies than the other. In all specimens for which both part and counterpart were available, however, there is a greater density of leaves on one side (hypothesized to be the adaxial) than on the other, caused primarily by an apparent abortion of leaf primordia early in development on the side of least density. Leaves and branches occur in the same ontogenetic spiral and in one specimen comprise a 'phyllotaxis' of $2 / 9$ and contact parastichies of $5+9$. On both the main and lateral axes, leaves are characterized by long, decurren bases which essentially ensheath the ax's on which thay are borne. Phyllotaxis and the correlated stelar form apparently vary considerably within Archaeopteris. It is suggested that Archaeopteris was more closely related to the coniferophytes than to any other gymnosperms.

OVER THE YEARS Archaeopteris has been of interest to many morphologists, due in part to its widespread occurrence, its frequently good preservation, and its Upper Devonian age. Considered early to be a fern, considerable botanical interest was aroused with the discovery by Arnold (1939) of heterospory in A. latifolia and further heightened upon the integration of Archaecpteris and Callixylon by Beck $(1960 \mathrm{a}, \mathrm{b})$. At that time, primarily on the basis of the nature of the secondary wood, I proposed that Archaeopteris was neither a fern, nor in any way directly related to the Filicineae, but rather, a progymnosperm-a representative of a group of gymnosperm precursors. There were two major problems that affected the immediate acceptance of this interpretation. The first concerned the possible difference between the morphology of the primary vascular system of Archaeopteris stems and that, of gymnosperms.

Under the influence of E. C. Jeffrey, many morphologists, especially in the United States,

1 Received for publication 22 February 1971.

Supported by grants GB-3038 and GB-8100X from the National Science Foundation.

I acknowledge with gratitude the technical assistance of Miss Nancy Chase who prepared most of the sections, the photography by Mr. Louis Martonyi, the art work by Mr. Derwin Bell, the assistance in collecting of $\mathrm{Mr}$. Philip Gehring, and the loan of a negative by Professor Chester Arnold. considered gymnosperms to have filicinean leaf gaps. The work of Namboodiri and Beck (1968a, b, c) corroborated the early conclusions of Geyler (1867) that the primary vascular system of conifers is composed of discrete sympodia of vascular bundles. Namboodiri and Beck, and more recently Beck (1970a), have emphasized that filicinean leaf gaps seem not to be present in systems of this type. Analyses of the primary vascular systems of Lyginopteris oldhamia by Scot: (1923) and Posthumus (1924) convincingly demonstrated the presence of discrete sympodia, and I have recently shown that similar systems characterize some members of the Calamopityeae (Beck, 1970a). Although our work on the stem stele of Archaeopteris (i.e., Callixylon) is as yet incomplete, results thus far strongly suggest that its primary vascular system is basically similar in morphology to that of both primitive pteridospermous gymnosperms as well as to extant conifers. All currently available evidence, therefore, supports the view that the primary vascular system of Archaeopteris is essentially identical with that of gymnosperms, and basically different from that of filicineans.

The second major problem was posed by the fern-like nature of the Archaeopteris 'fronds'. Although pteridosperms and cycadophytes are characterized by large, compound fronds, the apparent possession by Archaeopteris of such 
'fronds' seemed totally inconsistent with the conspicuously conifer-like anatomy of the stems (see Beck, 1970a).

Carluccio, Hueber, and Banks (1966) concluded, on the basis of internal structure, that the laminar appendages of the 'fronds' were helically arranged. They showed further that the vascular system of the main axis was radially symmetrical like that of a stem. These results led them to conclude that the 'fronds' of Archaecpteris macilenta are, in fact, not compound leaves, but rather, flattened lateral branch systems bearing simple leaves. Such lateral branch systems would, indeed, be very similar to those of conifers. If correct, this interpretation would remove the inconsistency noted above and would support my original hypothesis that Archaecpteris is a progymnosperm. There remained, however, certain major discrepancies between this interpretation based on internal structure, and the interpretations of numerous workers, based on study of compression specimens. Especially disconcerting was the apparent opposite or sub-opposite arrangement of pairs of 'rachial pinnules' in many specimens, as described by many different workers, and evidence, which I presented recently, of an apparent decussate arrangement of leaves on the ultimate axes of the lateral branch systems (Beck, 1970b).

The objectives of this study have been to correlate internal anatomy with external morphology in an attempt to understand or better explain these apparent discrepancies and, thus, to further clarify the morphology of lateral branch systems of Archaeopteris.

Material and methods-This study is based primarily on approximately 50 specimens filed under collection numbers 375 and 376 in the Paleobotanical Collection of the Department of Botany, University of Michigan. Collection 375 seems to be composed predominantly of a single species, Archaeopteris macilenta Lesquereux (1884). It is, of course, impossible to prove that a fertile specimen lacking vegetative leaves is $A$. macilenta, but its close association with a large number of specimens identifiable as this species, and the absence of any other recognizable species in the same collection, provide a good basis for making this conclusion. Such a specimen is $375-\mathrm{II}$, the main axis of which has provided the material for the anatomical study. It has also been impossible to positively determine the species of certain specimens similar in appearance to Eddya (Beck, 1967), consisting of axes bearing flabelliform leaves. It is a reasonable assumption, I believe, that they represent either apical or basal segments of the main axis of Archaeopteris lateral branch systems. Specimen 376 is most similar to Archaeopteris halliana (Goeppert) Dawson, emend. Arnold (1939), but it does not conform exactly to Arnold's re-description of this

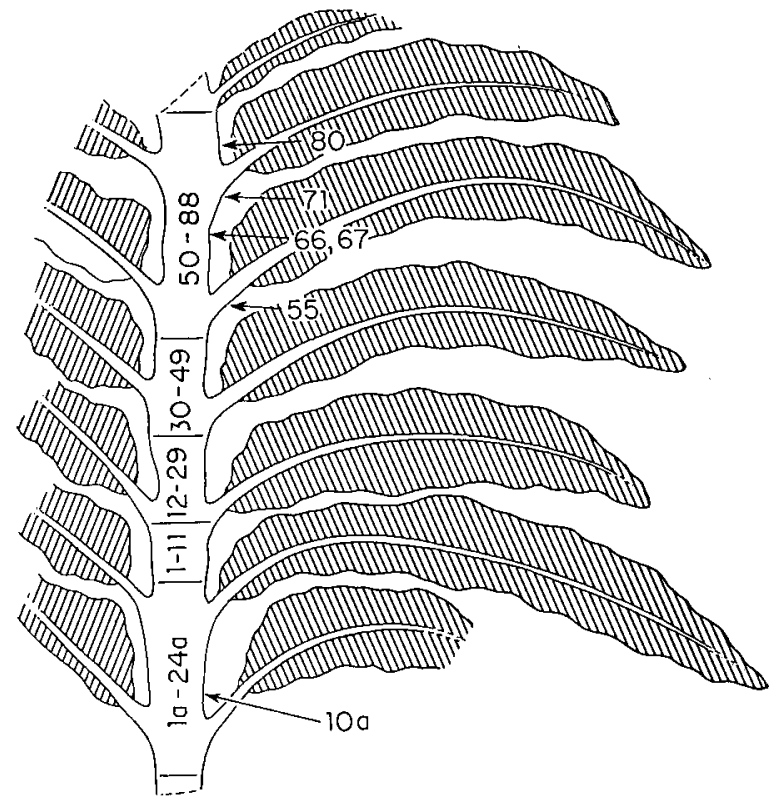

Fig. 1. Diagrammatic drawing of specimen 375-II, indicating position of sections.

species nor to the morphology of the type specimen.

The source of collection 375 is the Katsberg formation of Frasnian (lower Upper Devonian) age exposed on the southeast side of state route \#10, two miles northeast of the Cannonsville Reservoir dam, near Cannonsville, Delaware County, New York. Collection 376, consisting of a single vegetative specimen, came from Olin Canfield's quarry, Silvara, Bradford County, Pennsylvania. It is of Upper Devonian (Catskill) age.

Among these 50 specimens are both fertile and entirely vegetative specimens. Internal structure of the main axis was preserved in several specimens, primarily in iron pyrite. Two were preserved in limonite, and it was one of these latter that yielded the most information. The pyritized specimens had oxidized to such an extent prior to study that polished surfaces were impossible to prepare.

The limonitic axes were embedded in a methacrylate plastic, sectioned at about $200 \mu$ with a Gillings-Bronwill saw, mounted on glass slides with Lakeside thermoplastic cement, and ground to a thickness of 15-25 $\mu$. At this thickness the cell walls were dark to nearly opaque. Euccessful clearing was achieved by immersion of the sections in a $50 \%$ solution of $\mathrm{HCl}$ for from 5-20 min. The sections were then thoroughly washed in water and mounted, prior to drying, in light Karo syrup.

Compression specimens were prepared by carefully degaging with small steel needles under a dissecting microscope. To expose the leaf base 
pattern, the carbonaceous film was removed from the main and some lateral axes of the branch systems by careful chipping.

Drawings of both sections and compression specimens were made with the highly versatile Wild M-5 stereomicroscope and drawing tube attachment. Photomicrography was accomplished with $35-\mathrm{mm}$ Nikon photographic equipment and a Leitz microscope. Most of the compression specimens were immersed in water and photographed with Leitz photographic equipment. Surface detail of several specimens was emphasized by the use of unilateral lighting.

ANatomy CF ThE MaIN axis-The anatomical structure illustrated herein represents the axis of a single fertile specimen (375-II) (Fig. 1). Although two others (3\%0-O, a limonitic axis, and $375-\mathrm{L}(1)$, a pyritized axis) were sectioned, they were too poorly preserved to add significantly to this study. The axis of specimen $375-$ II was 11.5 $\mathrm{cm}$ long, with a diam of approximately $0.8 \mathrm{~cm}$. It was a limonitic axis and, though rather badly compressed, it was structurally preserved in part throughout its entire length. Consequently, it has been possible to compare its structure in widel $y$ separated regions ard to determine the phyllotaxis as well as the relationship between branch and leaf trace divergence. The entire axis was sectioned transversely, yielding 112 thin sections (Fig. 1).

General anatomical features-The axis is characterized by a central pith surrounded by a cylindrical system of primary xylem. The stelar cylinder consists of nine radiating ribs varying in degree of interconnection from none to extensive and enclosed by secondary xylem. This, in turn, is surrounded by a parenchymatous region of large cells in which occur leaf and branch traces (Fig. 2, 10, 21-26). Occasionally preserved, near the xylem, are clusters of thick-walled cells of small transverse dimension (Fig. 9). Leaf bases adherent to the axis may be seen in a few sections (Fig. 22, 26). Although the outer tissues of the axis are not very well preserved, there is some evidence of masses of thick-walled, sclerenchymatous cells intermixed with thinner-walled cells in the outer regions which apparently represent the sub-epidermal layers of decurrent leaf bases.

Connection between ribs of primary xylem, where it occurs, with one, possibly two, exceptions, is by a radially thin sheet of cells (Fig. 11, $22,24,26)$. The ribs from which leaf traces 9 and 13 diverge, however, are connected by a mass of cells of much greater radial extent (Fig. 3, 21, 22, 26). It is quite possible that ribs from which traces 8 and 12 diverge are also connected by a fairly thick sheet of cells as indicated by Fig. $2 t$ and 26 . This is not entirely certain, however, because of the rather poor preservation in this part of the axis. Carluccio et al. (1966) have shown that all of the ribs may be discrete in the basal parts of the axis and completely connected in more apical regions. This specimen, therefore, probably represents an intermediate position of the main axis of a branch system.

Tha seco dary xylem consists of files of angular, most commonly rectangular, tracheids and narrow rays. The tracheids on the average are larger in transverse radial dimension tha! in tangential. The metaxylem tracheids, though becoming radially elongate near their contact with the secondary xylem, are polygonal in contrast to the rectangular secondary tracheids (Fig. 3-6, 11, $14-16,42)$. They are larger on the average than tracheids of the secondary xylem.

The protoxylem consists of cells that are smaller and thinner walled than those of the metaxylem. Furthermore, the contrast in wall thickness between protoxylem cells, some being conspicuously very thin walled, suggests that it consists of both tracheids and parenchyma cells (Fig. 42).

Leaf and branch trace formation-The protoxylem regions are radially elongate, and except in regions just above levels of leaf trace divergence (Fig. 4) consist of two protoxylem poles connected by a sheet of protoxylem tracheids mixed, apparently, with parenchyma (Fig. 3, 5, 6, 42). Upon the separation of a trace, the outer pole is reconstituted within a longitudinal distance of 2 or $3 \mathrm{~mm}$, and the protoxylem poles again begin their radial separation which will culminate in the divergence of another leaf trace at a higher level (Fig. 4-6).

In the cortex the leaf trace consists of protoxylem and presumably a narrow sheath of enclosing metaxylem cells (Fig. 6). Although primary phloem must have comprised a part of the trace, there is no evidence of it in this material, and consequently the arrangement of xylem and phloem in the trace is unknown. In a position just outside the secondary xylem the leaf trace is circular in transverse outline and has a diam of approximately $185 \mu$. As it follows a steeply oblique radial course through the cortex and into the leaf base, it dichotomizes tangentially, resulting in two smaller bundles, each about $114 \mu$ in diam (Fig. 6-9). It cannot be determined

Fig. 2-9. Structure of the main axis of specimen 375-Ir. -Fig. 2. General features of anatomy. 375-II56. $\times 28 .-$ Fig. 3-9. Details of primary xylem, leaf trace origin, and leaf trace dichotomy. $S C$, secondary xylem; $P X$, protoxylem; $M X$, metaxylem; $L T$, leaf trace; $I T$, incipient leaf trace. $\times$ 88.-Fig. 3. 375-II $(-16)$.—Fig. 4. 375-II57.-Fig. 5. 375-II70.Fig. 6. 375-II57.-Fig. 7. 375-II60.-Fig. 8. 375-II16.-Fig. 9. 375-II65. 


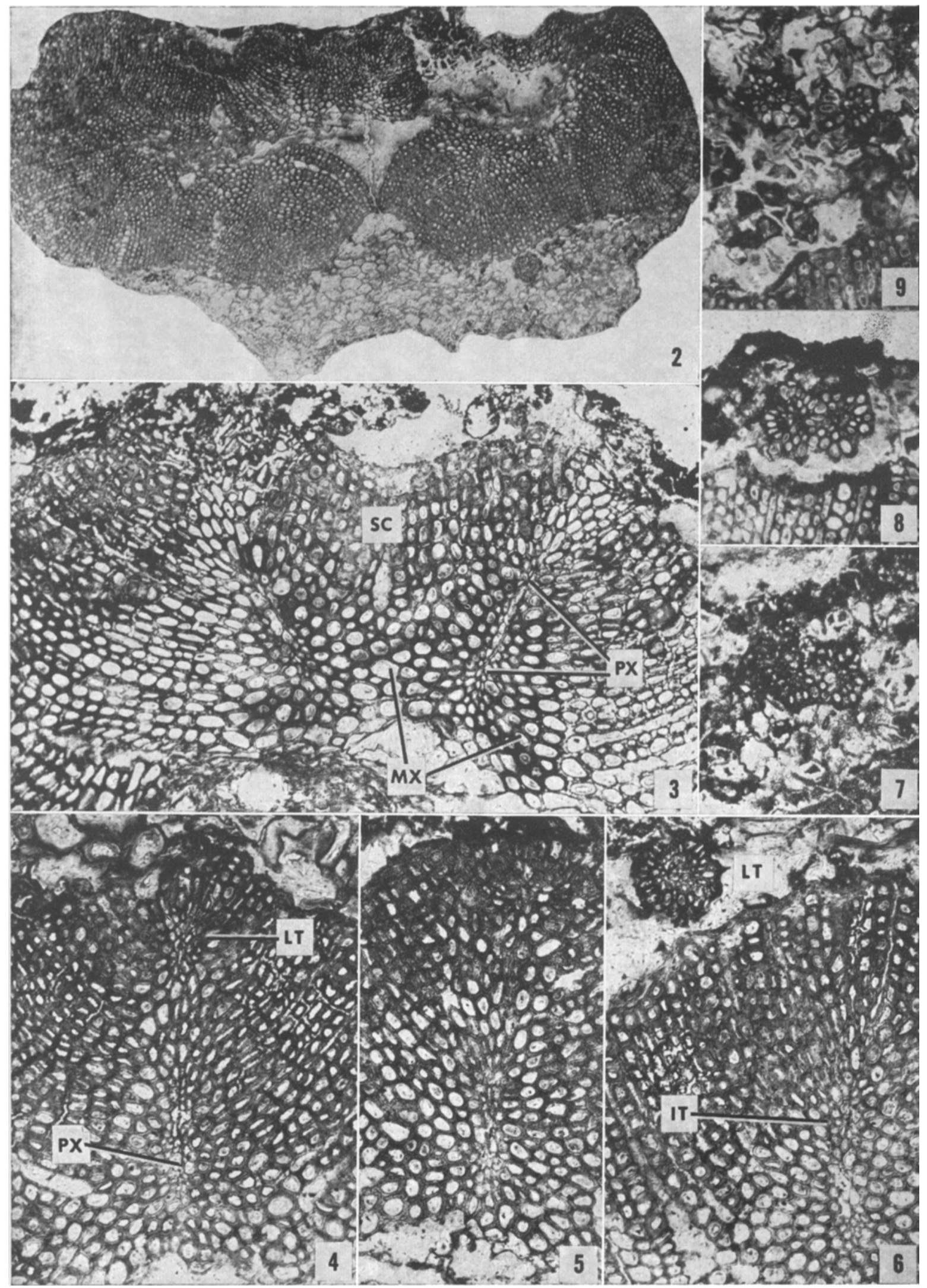




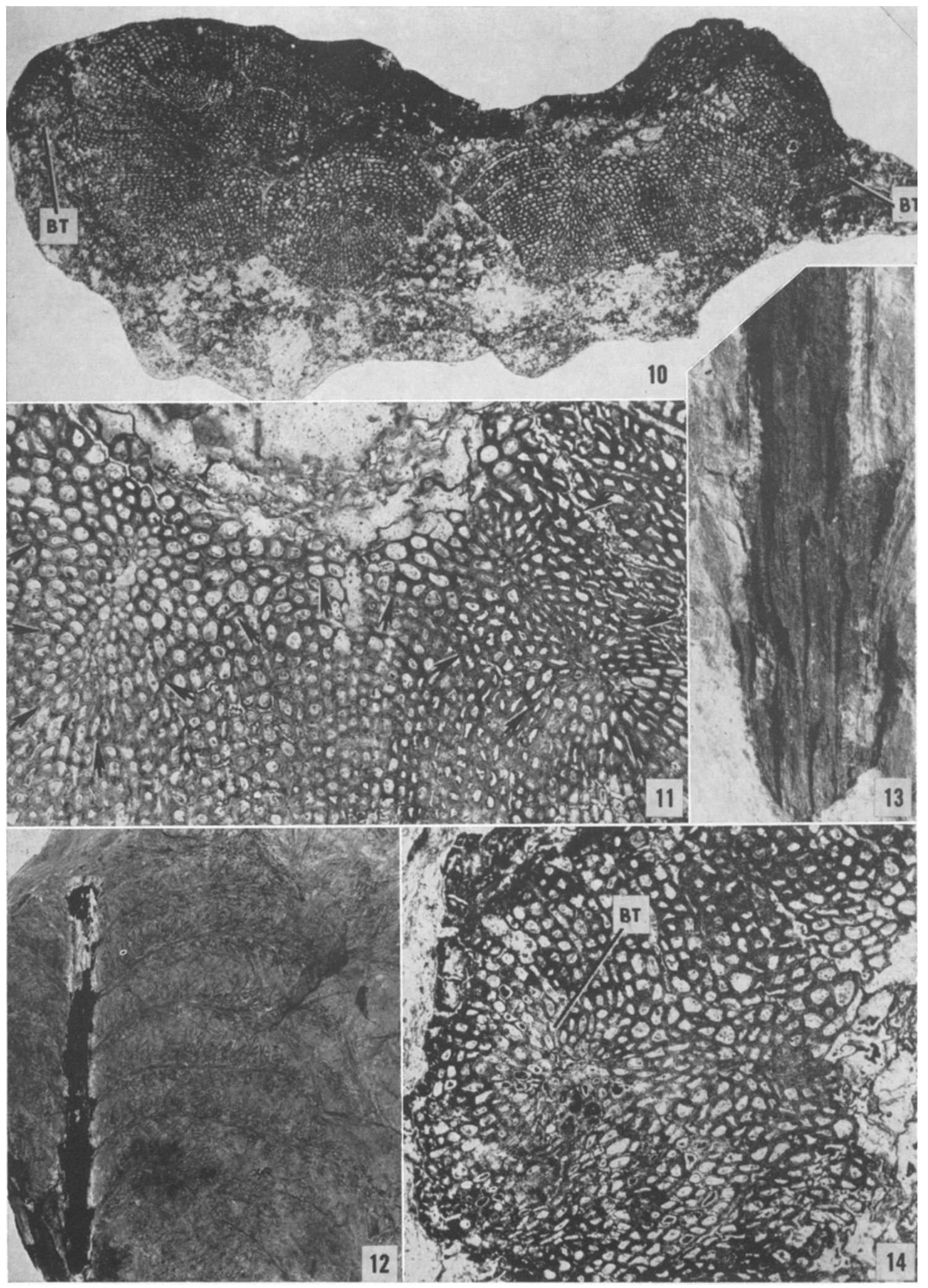


positively whether or not a second dichotomy occurs prior to entry of the leaf trace system into the leaf blade, but the rather wide tangential separation of traces as they continue longitudinally in the leaf base suggests this possibility.

Origin of branch traces seems to be identical to that of leaf traces (Fig. 14-16). The branch trace is initially similar to a leaf trace except that it is about 1/3 larger and at the level of separation from the rib, it is 4-angled, i.e., diamond-shaped, in section (Fig. 15, 16, 22, 23).

Because of the continuity of preservation throughout this relatively long axis it has been possible to determine that branch traces arise from only two of the nine ribs of the stele. Between these, on one side of the axis, are three ribs and on the other side, four ribs from which leaf traces diverge. It is, furthermore, clear that this pattern and certain structural details of the primary vascular system remain constant throughout the preserved length of the axis (Fig. 21-26). In the basal part of the axis cortical tissue is preserved along the upper surface only (Fig. 1, 21) but in the apical part cortical tissue is preserved along the lower surface (Fig. 1, 22-26). In no section is there any evidence of branch traces in these regions.

Sections 55, 66, 67, 71, and 80 have been selected from a region of the axis from which two subopposite pairs of branches diverge (Fig. 1). In section 55 (Fig. 22, 16), which comes from a level of branch divergence, the diamond-shaped branch stele is preserved on one side. A leaf trace to the basal leaf of this branch is also apparent. At this level, furthermore, the protoxylem strands have elongated in the two opposite ribs from which branch traces arise, and the two protoxylem poles have become conspicuous, the outer of which represent the next higher branch traces (Fig. 22, 16). Sections 66 and 67 (Fig. 23, 24) come from a level about midway between the sub-opposite pairs of branches (Fig. 1), and the two branch traces are obvious here. In section 71 (Fig. 25), just below the levels of divergence of the branches, both branch traces are conspicuous (see also Fig. 10). Immediately above these branches in section 80 (Fig. 1, 26), incipient branch traces may be observed in these same two ribs. There can be no doubt, therefore, that in this segment of the axis, branches, and only branches, arise in subopposite pairs from only two primary xylem ribs on opposing sides of the stele. The branch arrangement is, therefore, distichous. Nevertheless, the branch and leaf traces seem to occur in the same ontogenetic spiral, certainly one of the most interesting aspects of the morphology of this branch system.

Phyllotaxis-Upon observation of a series of sections it becomes clear that the leaf traces (and the incipient leaf traces) and thus, the leaves, are helically arranged. Leaf traces originate from every other rib, except that branch traces always occupy positions in the ontogenetic spiral along the two orthostichies represented by the two ribs from which they diverge. Consequently, leaf and branch traces have been given consecutive numbers indicating the order of their development (Fig. 21). The origin of traces from alternating ribs may be clearly observed in the series of sections illustrated in Fig. 21-26. It is apparent, furthermore, that if this interpretation is correct and if one includes the branch traces, the phyllotactic fraction is a very unusual $2 / 9$.

It should be noted that the pattern of the primary vascular system remains constant throughout the preserved length of this axis (compare Fig. 21 and 26). There is, in other words, no evidence of branching or fusion of ribs. (Evidence from external morphology, presented in a later section, will show, however, that there is variation in the number of orthostichies of leaves and thus, presumably, in the number of ribs). The nine ribs then seem to represent nine orthostichies of lateral appendages, seven of leaves, and two of branches. Because of the uneven number of orthostichies there will be, of necessity, an unequal number on the sides of the axis above and below the plane of the branches.

On the basis of this evidence a restoration of the structure of this axis as seen in transverse section (Fig. 27) has been prepared.

EXTERNAL MORPHOLOGY-This study of the anatomy of a main axis of an Archaeopteris lateral branch system corroborates and expands that of Carluccio et al. (1966). Remaining, however, is the apparent inconsistency between the helical arrangement of leaf traces and the viewpoint of many workers over the past 100 years, including the writer (see Beck, 1962, 1970b), that leaves along the main axis, i.e., 'rachial pinnules', are arranged in opposite or sub-opposite pairs. This view has been based on observations of literally hundreds of specimens similar to that shown in Fig. 35 and 36 . The presence of pairs of

Fig. 10-14. Anatomy and morphology of specimen 375-II.-Fig. 10. General view, showing sub-opposite arrangement of branch traces, BT. 375-II71. X 28. - Fig. 11. Continuity between 2 ribs of the stele. Metaxylem outlined by arrows. Cf lower right ribs of Fig. 25. 375-II56. $\times 88$.-Fig. 12. Fertile specimen which yielded the structurally preserved main axis. Cf Fig. 1. 375-II. $\times 0.57$.-Fig. 13. Part of surface exposed when structurally preserved axis of specimen 375-II was removed, showing leaf base pattern. $\times 3$.-Fig. 14. Rib of primary xylem at level of branch trace $(B T)$ divergence. $375-$ II60. $\times 88$. 
leaves along the main axis in this specimen is very conspicuous. But what seems to represent the whole truth in a plant fossil compression might, indeed, represent only a part of its complete morphology, In other words, the presence of pairs of leaves along the fossil axis does not necessarily preclude the presence of other leaves along that same axis which, because of certain factors relating to its encasement in an opaque matrix and its exposure by splitting of the matrix, have not previously been recognized. Since, however, our knowledge of internal structure has, thus far, come from only several specimens, it seemed quite possible that we might be dealing with more than one taxon. Might not some lateral branch systems of the Archaeopteris type be characterized by a main axis bearing opposite leaves, whereas others might have helically arranged leaves? Evidence seeming, initially, to support this possibility came from observation of specimens in my collection. The presence of an apparently opposite-leaved type was demonstrated by the specimen noted above (Fig. 35). Leaves of some other specimens, however, especially those that exhibit a terminal part of the main axis (Fig. 49) seemed to be arranged helically or at least alternately. Furthermore, in the type specimen of Archaeopteris halliana (see Arnold, 1939) a suggestion of helical leaf arrangement is apparent along the entire length of the main axis and especially strong in basal and apical regions (Fig. 50).

Still another specimen (Fig. 19) posed a new possibility - that its leaves might be whorled. There seemed to be three leaves at a node. At several nodes, however, one of the three was distinctly shorter, suggesting the possibility that it might be attached at a level different from the other two. Assuming this to be the correct interpretation, it became apparent that these third leaves might be members of pairs of leaves, the missing members being in the matrix of the counterpart. If so, the leaf arrangement would be decussate. This possibility was strengthened by study of the specimen illustrated in Fig. 38 and 39. Unfortunately, as in the case of the previous specimen, it was unknown whether or not this specimen was part of the terminal segment of a main axis of a branch system, a lateral axis, or the main axis of a young sporophyte (i.e., Eddya; see Beck, 1967). Three rows of leaves were visible on this specimen, one along the upper surface between two lateral rows (Fig. 38). By carefully chipping away the middle row it became apparent that each leaf was attached about midway between successive pairs of sub-opposite leaves (Fig. 39). Decussate leaf arrangement seemed a distinct possibility. Attempts by further degagement to determine the exact points of attachment of leaves on the back side of the axis were unsuccessful.

At this stage of the investigation it seemed possible, therefore, that there might be, within A rchaeopteris, three different morphological types of lateral branch systems, distinguished by opposite and distichous, decussate, or helical arrangement of leaves on main axis.

The first major breakthrough in the interpretation of the morphology of compression specimens came with study of another specimen which seemed initially to have opposite to sub-opposite leaf arrangement (Fig. 51). Careful study, however, revealed faint outlines of what appeared to be elongate leaf bases (Fig. 52). If these did indeed represent decurrent leaf bases (and it seemed almost certain, because of evidence from the anatomical study, that they did), this opened the possibility of new information and, thus, possibly a new and accurate understanding of the morphology of the main axis-perhaps the entire branch system.

INTERPRETATION OF THE COMPRESSION SPECIMENs-Upon discovery of a leaf base pattern in one specimen, the entire collection was carefully examined, and it was determined that leaf bases could be observed in almost every specimen. They were visible, however, only in regions from which the carbonaceous material of the fossil was missing. In other words, they were visible only on the impressions (Fig. 17). Since knowledge of the position of the leaf bases was necessary for an accurate interpretation of the morphology of the branch systems, the carbonaceous material was carefully chipped away from the axes of all specimens studied, revealing a remarkable pattern of leaf bases (Fig. 28-34; 46A, B; 48A, B).

The leaf base patterns revealed in the two impressions of a main axis seemed to differ on part and counterpart. It was, therefore, necessary to determine whether all of the leaves of the axis were represented on each impression, the apparent differences in pattern the result of variation in preservation, or whether, in fact, the variant patterns represented two different sides of the same axis. It is now clear that the latter alternative is correct. In reaching an understanding of why this is true, the reason for the past misinter-

Fig. 15-20.-Fig. 15, 16. Branch trace divergence. $B T$, branch trace; $I B T$, incipient branch trace. $\times 88 .-F i g .15$. 375-II66.-Fig. 16. 375-II56.-Fig. 17. Archaeopteris macilenta. Leaf base pattern is revealed upon removal of carbonaceous film. 375-G. $\times$ 3.7.-Fig. 18. Fragment of axis with 5 orthostichies of leaves. 375-JJ. $\times 2.2 .-$ Fig. 19. Axis bearing leaves which appear, superficially, to be whorled. See text for explanation. 375-E. $\times 1.6$. Fig. 20. Archaeopteris macilenta. Lateral axes bearing leaves in apparent sub-opposite and decussate arrangement. $375-\mathrm{MM} . \times 3$. 


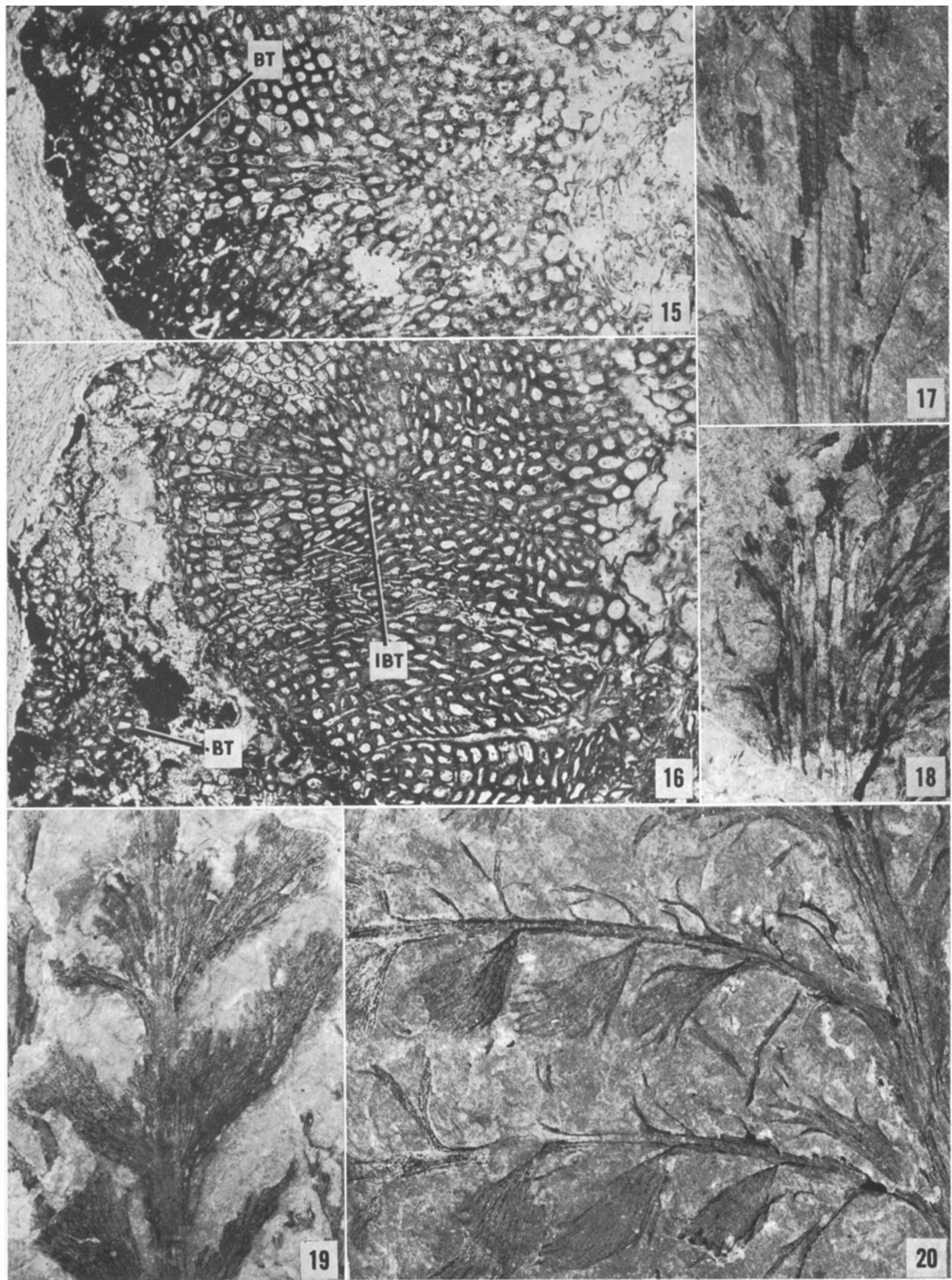


pretation of the morphology of the Archaeopteris lateral branch system became readily apparent.

When a specimen with radially symmetrical form is embedded in a matrix, compressed, and subsequently exposed by a splitting of the matrix, it is impossible to observe on the surfaces of part and counterpart all of the lateral appendages. This will be true for all categories of appendages unless they are arranged distichously (i.e, in two ranks in one plane).

As may be envisioned by observing Fig. 43A, when a sediment containing a compressed axis is broken open, the plane of the break (dark line) will usually occur on one side or the other of the compressed, lenticular (in section) carbonaceous material of the fossil. If the axis bears leaves in a uniform distribution on both sides, it will, therefore, be impossible to observe all of the leaves by observing part and counterpart (Fig. 43B). In fact, assuming the break will occur along any of the several lines indicated, only the more laterally placed leaves on one side will appear on the surface of the specimen (Fig. 43B, 45) and the same leaves that are thus exposed will appear on both part and counterpart (Fig. 28, 29). The median row (or rows) of leaves on the side of the break will remain in the matrix as will all of the leaves on the other side of the specimen (Fig. 43B). It now becomes clear, therefore, why the leaf arrangement on the main axis of the Archaeopteris lateral branch system has been misinterpreted in the past. Evidence presented later will provide a full explanation for the appearance of pairs of leaves on this axis in compression specimens.

The long, decurrent leaf bases of Archaeopteris essentially cover the main'axes of the branch systems, being separated from each other by narrow grooves (Fig. 27-34, 46A,B). When the carbonaceous material of such an axis is removed (Fig. 44), these leaf bases are revealed by the pattern of ridges formed by the matrix which filled the depressions between leaf bases. It is very clear, therefore, that this pattern on part and counterpart represents the leaf bases on the two different sides of the compressed axis (i.e., the adaxial and abaxial sides above and below the plane of the branches). These sides can be validly compared in different specimens because the distichous branching made it virtually certain that all lateral branch systems would be preserved in a similar horizontal orientation, except, of course, that they might be oriented upside down in relation to each other. The determination of the adaxial and abaxial surfaces of the branch systems will be discussed later.

Since the pattern that one observes upon removal of the carbonaceous material represents the leaf bases on the outer surface of the axis away from the observer, any leaves that are visible will necessarily join the surface of the axis from below the level of the axis (Fig. 44). This is very clearly illustrated in Fig. 37, which is a segment of the axis shown in Fig. 28. This type of evidence, indeed, proves that the pattern revealed is a leaf base pattern since it clearly shows the attachment of leaves and leaf bases.

The LEAF B ASE P.ATTERN-Three specimens, $375-\mathrm{G}, 573-\mathrm{Y}$, and $375-\mathrm{Z}$, for which part and counterpart are available, have been studied in great detail. These are consistent in the morphology of the main axis, including a similar variation in morphology on the two sides of the axis of each. Specimens $375-\mathrm{Y}$ and $375-\mathrm{Z}$ are fertile in their more basal parts and vegetative apically, but show no variation in morphology of the main axis in these different regions.

The main axis-As shown by the pattern of leaf bases in specimen $375-\mathrm{Y}$, the leaves are arranged on one side of the axis in three longitudinal rows (orthostichies) (Fig. 28, 46A). Because there are only three rows, and the leaves are rather widely separated along the orthostichies, the helical pattern is not immediately apparent. In fact, the longitudinal alternation of sub-opposite pairs of leaves in the two Iateral rows with a single leaf of the middle row is initially most conspicuous. When, however, one observes the specimen more carefully, there appears to be a series of helical contact parastichies which include the lateral branches, a feature which is equally clear in other specimens (Fig. 48A,B). On the reverse side of the axis, the leaves occur in four orthostichies (Fig. 46B). (Because of poor preservation along one edge of the axis, evidence of the fourth leaf orthostichy is not very apparent in a photograph. There is, however, no doubt of its presence. Four leaf orthostichies, represented by the leaf base pattern, may be clearly seen in a different specimen illustrated in Fig. 53). Surprisingly, on this reverse side leaves occur in greater frequency per unit length of axis than on the other, and there is not the clear relationship between leaves and branches that exists on the other side. On the one side there are 14 leaves represented (Fig. 46A) whereas on the opposite side there are 27 leaves (Fig. 46B)! Initially, I assumed the differences to be related to poor preservation on the side bearing the fewer leaves, but careful examination of the specimen did not seem to support this possibility. Furthermore, upon careful study of the other specimens, the same condition was found to exist in each of them -more leaves on one side than on the other (Fig. 32-34; 48A,B). Most surprising is the fact that the greater number of leaves on one side cannot be accounted for by an additional orthostichy on that side since there are only about eight leaves in each orthostichy on the axis segment of specimen $375-\mathrm{Y}$. Clearly then, the difference is related, more importantly, to the presence of fewer leaves in the orthostichies on the opposite side, each containing in this axis 


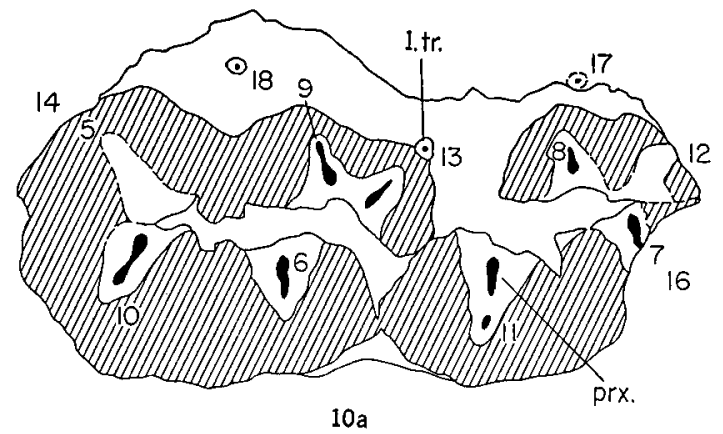

(21)

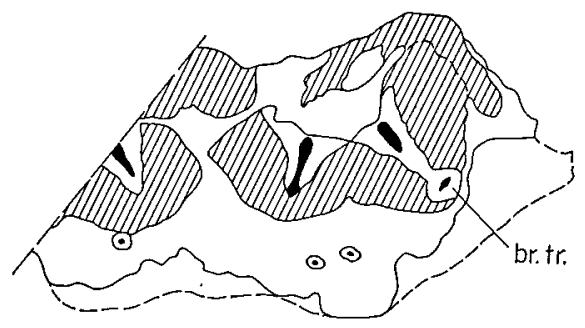

66

(23)

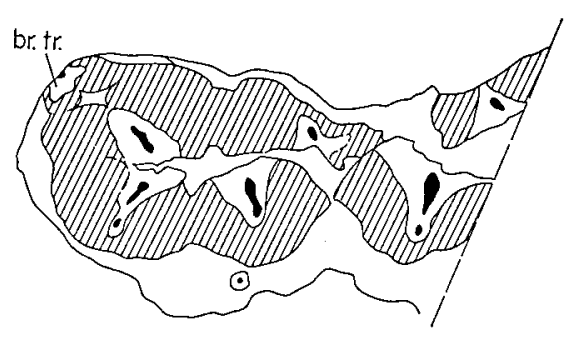

67

(24)

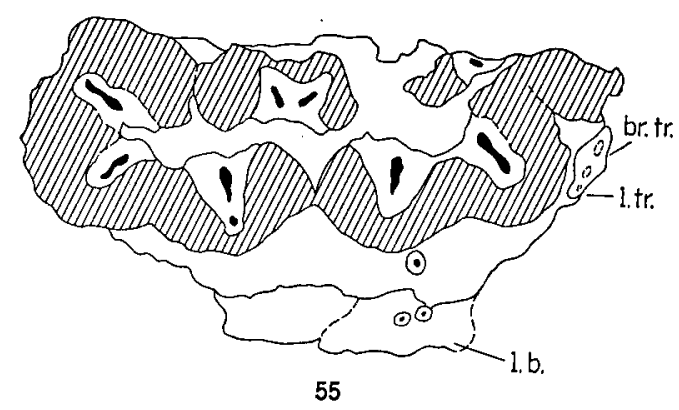

(22)

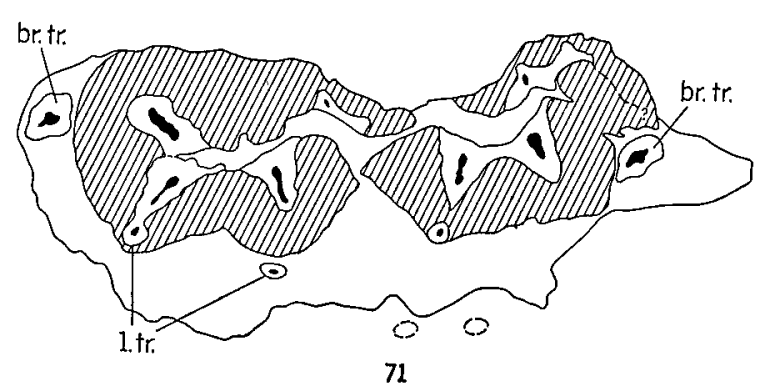

(25)

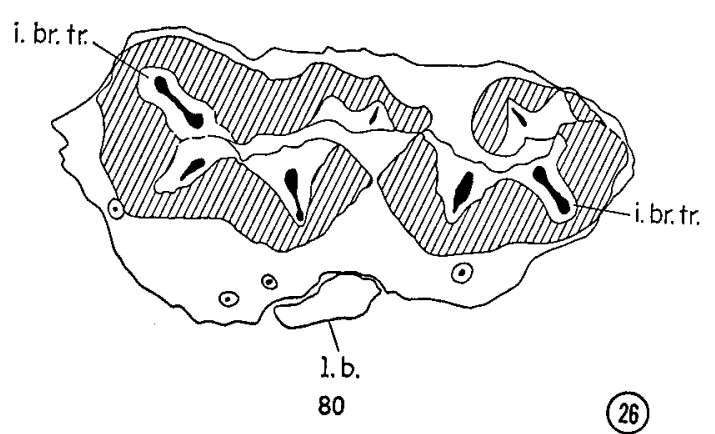

Fig. 21-26. Camera lucida drawings of sections selected from the main axis of specimen 375-II, illustrating constancy of stelar pattern, pattern of leaf and branch trace origin, and presence of leaf bases. Relative positions of these sections may be determined by reference to Fig. $1 . p r x$., protoxylem; $l . t r$, leaf trace; $b r . t r .$, branch trace; $i . b r . t r$., incipient branch trace; $l . b$. , leaf base; shaded, secondary xylem. Further explanation in the text.

segment only about five. The inescapable conclusion is that more leaves developed in a comparable area on one side of the axis than on the other.

What sort of phyllotaxis would characterize such a plant? It quickly became apparent that it was impossible to determine the phyllotactic fraction. The morphology of this axis seemed so unusual that I decided to plot the positions of the leaves and branches on each side of the axis in a single diagram which would represent the entire phyllotactic pattern of the axis, and seen as if the surface of the axis had been peeled off and laid out flat (Fig. 47). This diagram was made directly from the drawings in Fig. 46A,B by plotting the positions of leaves (circles) and branches (squares), indicating the orthostichies on each side of the axis as vertical lines, spreading them apart, and placing them together in a single drawing. The circles indicate the approximate levels at which the blades of the leaves diverged from the leaf bases. The positions of the squares were more difficult to determine, but represent, in my judgment, the approximate levels of entry of the branch steles into the bases of the branches. Nine orthostichies are represented, two of branches and seven of leaves, and two series of contact parastichies are obvious. The diagonal lines that 


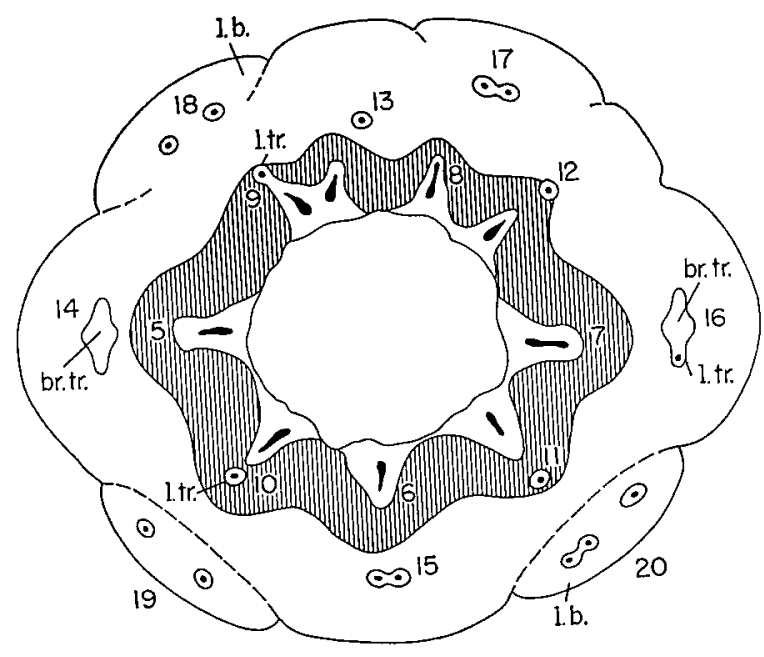

Fig. 27. Restoration of a transverse section of the main axis of specimen 375-II from a level of divergence of lateral branches. Based on the sections illustrated in Fig. 21-26, and others from the same axis. Succession of development of leaf and branch traces is indicated by numbers, the higher numbers indicating older, the lower, younger traces. For abbreviations see legend to Fig. 21-26. Further explanation in the text.

extend across the diagram from left to right represent segments of one set of continuous parastichies, segments of different continuous parastichies being indicated by the same kind of line. All parastichies of the second set are shown as solid lines.

In addition to the continuous parastichies, there are two sets of discontinuous parastichies restricted to one side of the axis. It should be noted that there are 13 more leaves on this side than on the other, and that these lie along the discontinuous parastichies. It is important, furthermore, to observe that all of the branches, and all of the leaves, on the other side of the axis lie along continuous parastichies. It should also be observed that in this specimen, in which lateral appendages occur in nine orthostichies, the branches are basically sub-opposite but, due to slight variation in distance between appendages along each orthostichy, they may appear nearly opposite or nearly alternate.

I propose the following explanation for this unusual morphology: During development leaf and branch primordia were probably initiated regularly around the apical meristem; early in development primordia along certain contact parastichies on one side of the axis must have aborted, thus leaving the discontinuous parastichies of mature leaves and resulting in a greater density of leaves on one side than on the other.

As noted above, this inequality in density of leaves on the two sides of the axis is a constant feature in the three specimens for which part and counterpart were available (compare Fig. 46A,B with $48 \mathrm{~A}, \mathrm{~B})$. The number of leaf orthostichies, however, is variable. Specimen $375-\mathrm{G}$, in contrast to $375-Y$ (described above), has six leaf orthostichies, three on each side (Fig. 48A,B; compare Fig. 31 and 48B) and two branch orthostichies for a total of eight. Carluccio et al. (1966) described primary vascular systems with eight and ten ribs, suggesting that there could be either an equal number of leaf orthostichies on each side, as in my specimen 375-G, or two more on one side than on the other. Their Fig. 18 suggests that the latter condition applies in a specimen with ten ribs. This asymmetrical condition also clearly applies to Siderella Read (1936). In the third specimen, $375-Z$, there are only five orthostichies of leaves and the branches are distinctly alternate (Fig. 3234 ). The alternate branching appears to be related to the number of orthostichies and the longitudinal distance between appendages, i.e., the slope of the parastichies. On one side of this specimen there are only two rows of leaves (Fig. 32 ), whereas there are three leaf orthostichies on the other (Fig. 33, 34). It is of particular interest, furthermore, that in the basal region of the main axis of this specimen (Fig. 33), leaves apparently occur in the same orthostichies along which, at a higher level, branches occur (Fig. 34).

Contrasting with those previously described are several fragmentary specimens of considerable interest in that they provide evidence of the presence of five orthostichies on one side of an axis (Fig. 18). In these specimens both leaves and branches are vertically more closely spaced in the orthostichies than in the specimens with fewer orthostichies. This might result from less longitudinal growth in these axes, which are somewhat thicker than those bearing fewer orthostichies of appendages. Since the leaves and branches occur in the same ontogenetic spiral it is obvious that when leaves are vertically close together in the orthostichies, the branches will be equally close together vertically as illustrated by Fig. 53 .

Several generalizations regarding the main axis of Archaeopteris lateral branch systems emerge from these observations:

1) Leaves and branches occur in the same ontogenetic spiral and, thus, in the same contact parastichies.

2) One side of the axis is characterized by a greater density of leaves than the other.

3) The two sides of an axis may have an equal number of leaf orthostichies, or they may differ in number by one or two.

4) The inequality in leaf density is caused not only by the presence of the one or two additional orthostichies where they occur, but more importantly, by a probable abortion of leaf primordia on one side during early development (as suggested by the presence of discontinuous contact parastichies).

5) There may be as few as two, or as many as five, orthostichies of leaves on one side of an axis. 


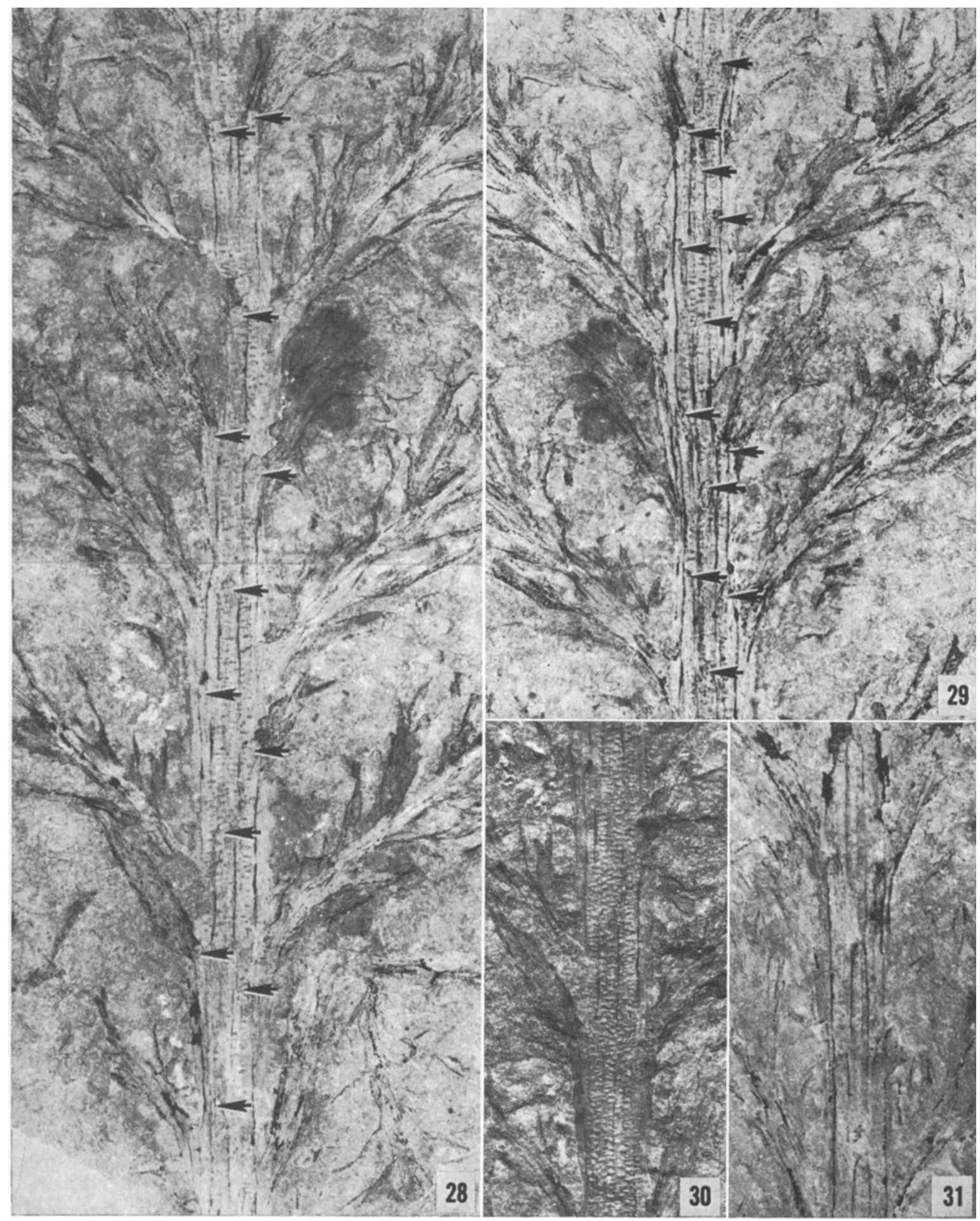

Fig. 28-31. Archaeopteris macilenta.-Fig. 28-30. 375-Y. × 2.2.-Fig. 28, 29. Part and counterpart. Note variation in frequency and size of leaf bases (arrows); also the occurrence (Fig. 28) of branches and leaves in the same contact parastichies. Cf Fig. 46A, B.-Fig. 30. Pattern of depressions in impression of axis, caused by masses of sclerenchyma.-Fig. 31. Leaf base pattern. 375-G. $\times 2.9$. 
6) Branches occur in two orthostichies on opposing sides of the axis, i.e., they are distichous. In the basal and apical parts of the axis leaves may apparently occur in these orthostichies.

7) Branch arrangement, i.e., whether nearly opposite, sub-opposite, or distinctly alternate, is dependent on the number of orthostichies and the distance between appendages in an orthostichy.

8) Because branches and leaves develop in the same ontogenetic spiral they are separated longitudinally in the orthostichies by similar distances.

9) The axis may be characterized by a total of from 7-11 orthostichies of appendages. [Direct evidence for 7,8 , and 9 , and indirect evidence for 11 is presented herein. Carluccio et al. (1966) provide evidence for 8 and 10.]

CoRRElation OF ANATONIY AND MORPHOLOGYIn every major aspect, the internal structure of the main axis of specimen 375-II correlates exactly with the external morphology of compression specimen $375-Y$. In the structurally preserved axis there are nine stelar ribs: two on opposite sides of the stele that produce sub-opposite branch traces and seven from which leaf traces divergethree on one side, four on the other side of the plane of the branches. This structure is exactly consistent with the sub-opposite arrangement of branches in one plane on one side of which there are three rows of leaves (represented in large part by. decurrent leaf bases), on the other side of which there are four rows, as illustrated in specimen 375-Y. The development of leaf and branch traces in the same ontogenetic spiral is reflected very clearly in compression specimens by the occurrence of leaves and branches in the same contact parastichies. The divergence of traces from alternating ribs along the ontogenetic spiral is expressed externally by the longitudinal alternation of nearly opposite pairs of leaves (or leaf bases) in the two lateral orthostichies (when there are only three) with one from the middle orthostichy. A similar appearance on the side with four or more orthostichies may result because one or more of the orthostichies along one edge of an axis are often very poorly preserved and thus inconspicuous. Where there are four or five rows of leaves in a well-preserved specimen, however, the helical arrangement of the leaves provides the dominant impression (Fig. 18, 53).

The very common appearance of 'pairs' of leaves along the main axis of compression specimens (Fig. 35, 36) is caused by the retention in the matrix of the leaves of the orthostichy running along the middle of one side of the axis (compare Fig. 36 with Fig. 28, 46A). With this knowledge, however, careful observation of the surface of the carbonaceous film of a compression specimen may reveal evidence of some of the leaves of the middle orthostichy (Fig. 36, at arrows). In some cases where the break is fortuitous, this 2 and 1 pattern of alternating leaves may be quite apparent as in the type specimen of Archaeopteris halliana (Fig. $50)$.

Direct evidence of the relationship between the anatomy and surface morphology, as interpreted herein, is provided by the pattern of leaf bases revealed when the structurally preserved main axis of specimen 375-II was removed for embedding (Fig. 13). It is, indeed, identical with that of the compression specimens with three rows of leaves along one side.

OTHER ASPECTS OF MORPHOLOGY-Throughout this study many other aspects of morphology of lateral branch systems have been observed such as: the arrangement of leaves and fertile appendages on the lateral axes, the morphology of these leaves and fertile appendages, the distribution of leaves and fertile appendages on lateral axes, the arrangement of fertile and solely vegetative lateral axes ('pinnae') in the branch systems, variation in leaf morphology and size within the branch systems, and certain surface features of the main axis. Much of this work is still in progress, and I shall include only a brief discussion of several of these aspects of morphology at this time.

Arranjement of leaves on the lateral axes-Evidence for a possible decussate arrangement of leaves on some lateral axes has been observed in a specimen of Archaeopteris macilenta (Fig. 20, 40, 41). Fertile appendages seem to be arranged along a lateral axis in opposite to sub-opposite pairs (Fig. 41). There is an appendage between each of these pairs on the back side of the axis, judging from the prominent leaf base scars. It is reasonable to assume that an opposing leaf, embedded in the matrix of the counterpart, would form the second member of pairs in this plane. Unfortunately this cannot be proven because the counterpart is not available. Evidence in another part of this specimen, however, suggests that this interpretation is correct. A vegetative lateral branch was oriented in the sediment so that, upon splitting of the matrix, the leaves exposed along the axis represent pairs alternating in planes at right angles (Fig. 40). Those leaves on the right side of the specimen are clearly in a plane at right angles to the surface of the photograph as can be determined by the orientation of the leaf bases, whereas those on the left are in the plane of the photograph. At two nodes evidence of the base of the blade of leaves directly opposite and in the same plane as those on the left can be seen (Fig. 40, at arrows).

Somewhat similar evidence in presented in Fig. 20 in which fragments of one member of a presumed pair alternate with pairs of leaves.

I conclude, therefore, that the appendages of this specimen of Archaecpteris macilenta are probably decussate on the ultimate axes of the branch system. To avoid confusion, it should be 


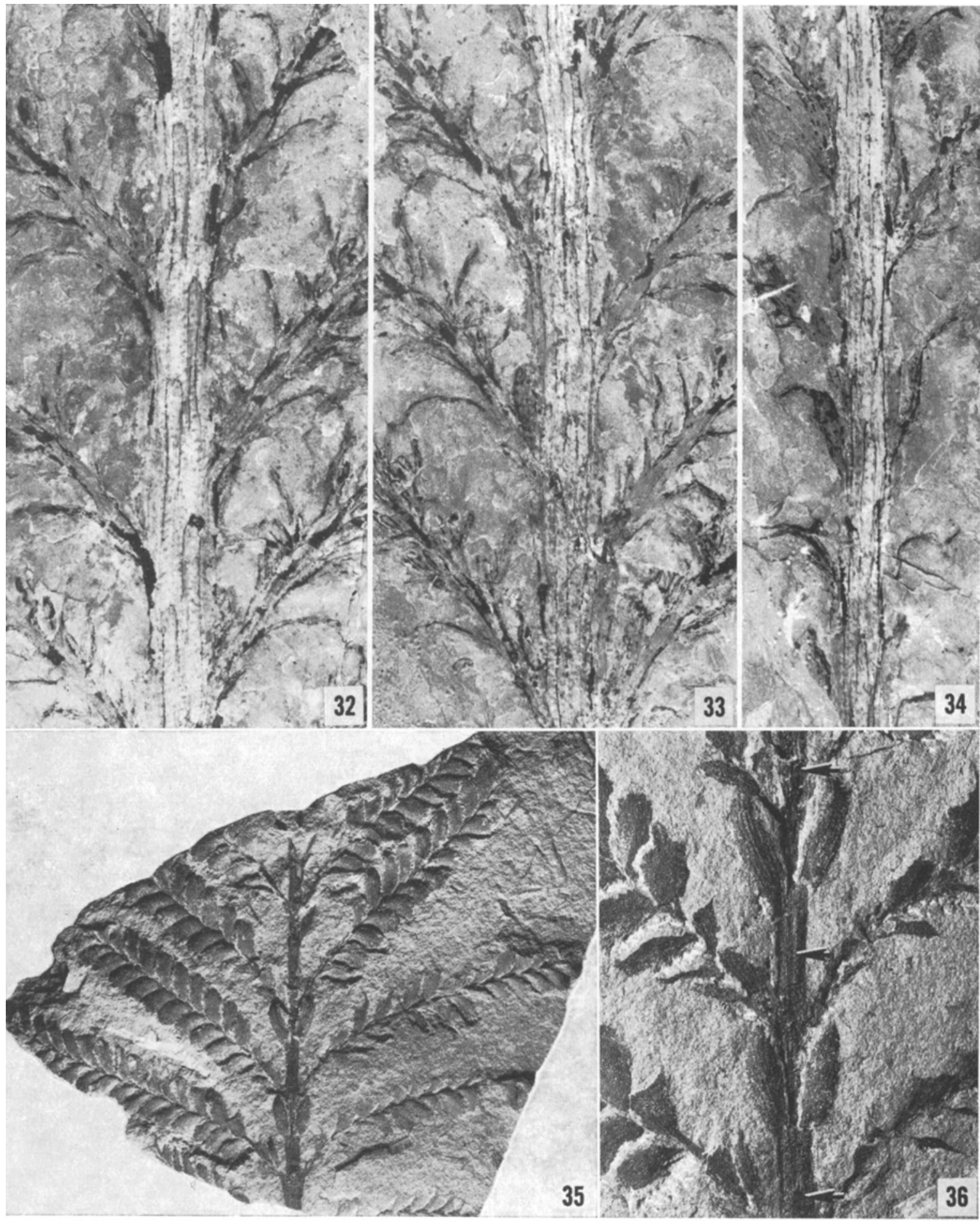

Fig. 32-36.-Fig. 32-34. Archaeopteris macilenta. Part (Fig. 32) and counterpart (Fig. 33, 34) showing the variation in the leaf base pattern on the two sides of the axis and the alternate, distichous arrangement of the branches. 375-Z. $\times$ 2.2. - Fig. 35, 36. Archaeopteris sp. 376.-Fig. 35. $\times 0.57$.-Fig. 36. Leaves on main axis appear to occur in pairs in two lateral orthostichies. Note remnant of leaf and position of attachment of other leaves in middle orthostichy (arrows). $\times 1.5$. 

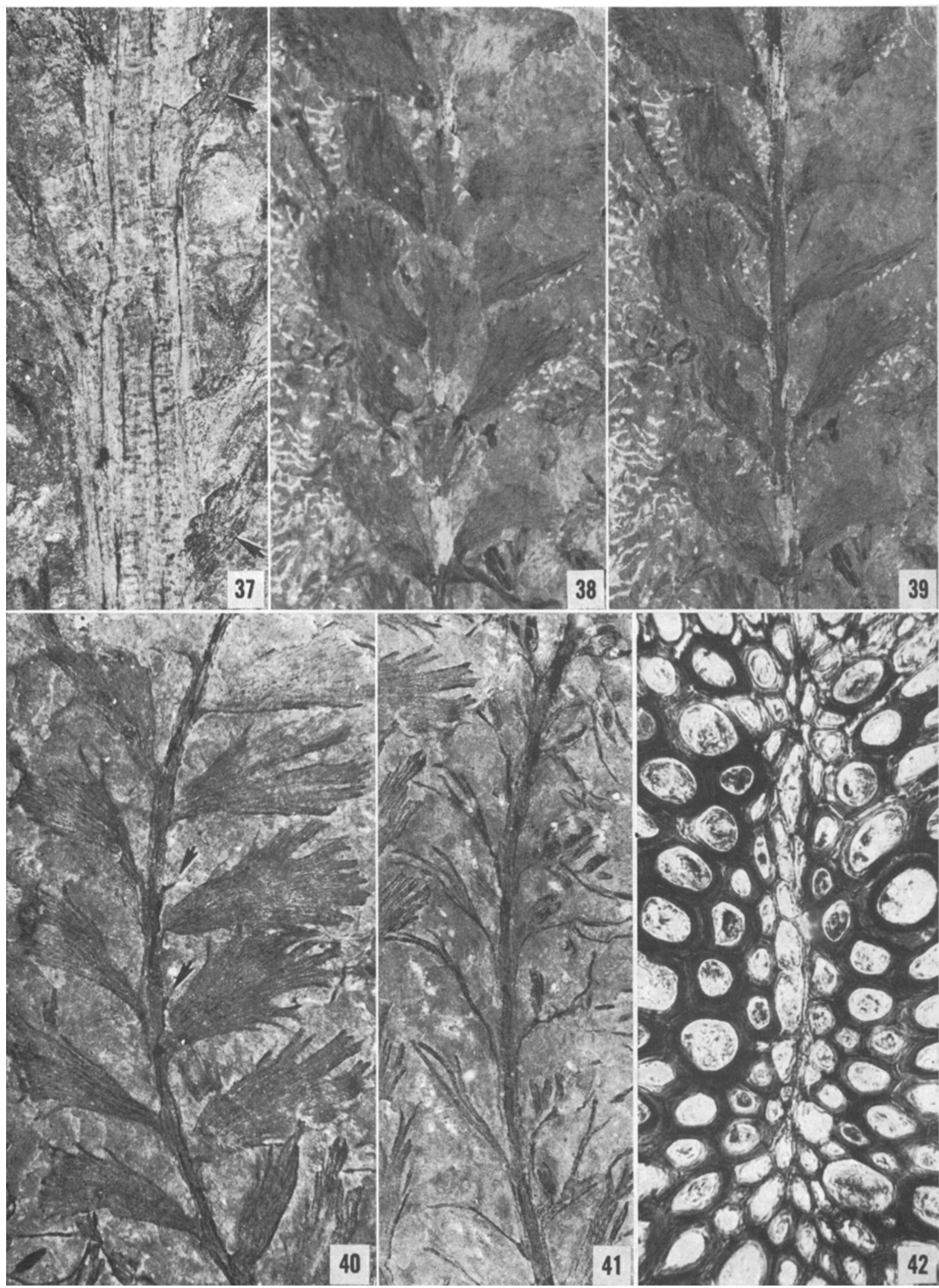
noted however, that a decussate arrangement may also be interpreted as a helical arrangement with a $1 / 2$ phyllotaxis. A helical appearance is most conspicuous when appendages in four ranks occur in sub-opposite pairs.

Variation in form and size of leaves-One's initial impression is that the leaves on the main axis vary in both size and form from one region to another. Those in the apical region of a specimen of $A$. halliana seem to be much larger and more flabelliform than those elsewhere along the axis (Fig. 50), but I believe these differences are related to variation in the plane of the break adjacent to different regions of the specimen and thus do not indicate actual major differences in size or form of the leaves. In the apical region some of the leaves are well exposed since they were nearly parallel to the plane of the break, whereas those elsewhere along the axis were lying at an angle to the plane of the break and thus, the apical regions of the blades were retained in the matrix of the counterpart. The leaves of both an apical (Fig. 49) and a probably basal part (Fig. 51, 52) of main axes of $A$. macilenta seem larger and more broadly flabelliform than those at intermediate levels (Fig. 28), but this comparison may not be meaningful since the three different parts represent different branch systems, and the differences, especially in size, might be environmental rather than genetic.

The possibility of variation in leaf size on different sides of the same main axis seems, however, to be a very real one. This was first suggested by the rather striking size difference between the leaves in the row along the upper surface of the specimen shown in Fig. 38 and those of the lateral rows. I was reminded of the condition in some conifers; for example, Tsuga, in which there is a row of very small leaves along the adaxial surface of the branch system. If the branches occur midway between the adaxial and abaxial sides of the main axes of Archaecpteris lateral branch systems, it seems logical that the leaves on the side of greatest leaf density might be smaller than those on the other because of less space available for their development. Positive evidence for such size variation is the presence of narrower leaf bases on the side of greater leaf density (Fig. 28, 29;46A,B;32-33) than on the opposite side.

In the specimens of this study there is a dis- tinct difference in either size or form between the leaves of the main and lateral axes. The size difference is conspicuous in A. macilenta (Fig. 28, 29) and the type specimen of $A$. halliana (Fig. 50), whereas in my specimen 376 ( $A$. halliana according to Arnold's 1939 key) the 'rachial' leaves are about equal in length to those of the lateral axes, but rather narrowly ovate in contrast to the more broadly obovate or flabelliform shape of the latter (Fig. 35, 36).

This rather conspicuous difference between two specimens that key out to the same species confirms Arnolds' (1939) view that we simply do not as yet know what constitutes a species in Archaeopteris. There can, however, be little doubt that leaf form and margin serration do provide important bases for the separation of groups of specimens. The three groups of specimens of this study, representing at least two distinct taxa, possibly three, can be easily separated on the basis of the 'rachial' leaves alone. Those of $A$. macilenta are narrowly to rather broadly flabelliform with deeply dissected margins (Fig. 28, 29, $51,52)$; those of $A$. halliana broadly flabelliform with entire or finely serrate margins (Fig. 50); and those of Archaeopteris sp. (my specimen 376) narrowly ovate with finely serrate margins (Fig. $35,36)$.

Finally, it is clear that there is considerable variation among leaves on the lateral axes. As is already well known, there is a size decrease toward the end of each lateral branch. We have some evidence, furthermore, that there is a gradual decrease in size of leaves of the lateral axes from base to apex of the branch system. That is, leaves on lateral axes near the base of the branch system are larger than those in comparable positions on lateral axes nearer the apex of the branch system. This is a point that we shall emphasize and document in a later paper.

Not only may there be variation in size, but also in form, of appendages on the lateral axes of a branch system. The conspicuous variation in form, of course, is between the vegetative leaves and the fertile appendages; but here I want to emphasize the striking variation in morphology of vegetative leaves on the same lateral axis of a specimen of $A$. macilenta, some of the leaves being characterized by slender, dichotomous laminar filaments; others, in form, typical of vegetative leaves of this species (Fig. 20). Dichotomously branched vegetative appendages also are borne on

Fig. 37-42.-Fig. 37. Archaeopteris macilenta. Details of impression of main axis of lateral branch system. Note orientation of leaves (arrows) below level of axis. 375-Y. $\times$ 3.7.--Fig. 38, 39. Archaeopteris macilenta (?). Specimen before and after removal of a middle row of leaves, suggesting arrangement of leaves in sub-opposite pairs and four ranks. $375-\mathrm{Q}$. $\times$ 0.6.-Fig. 40, 41. Archaeopteris macilenta. 375-MM. $\times 3$.-Fig. 40. Vegetative lateral branch with apparent decussate phyllotaxis. Note evidence of base of leaf blades at arrows.-Fig. 41 . Fertile lateral branch with nearly opposite pairs of appendages alternating along the axis with leaf base scars suggesting decussate phyllotaxis.---Fig. 41. Transverse sections showing detail of primary xylem. Note two protoxylem poles the upper of which will contribute to the next leaf trace to originate in the orthostichy represented. $375-\mathrm{II}(-16) . \times 342$. 
a lateral axis which, in addition, bears fertile appendages of similar form (Fig. 41). On an adjacent lateral axis the leaves are of typical vegetative morphology (Fig. 40). Other specimens
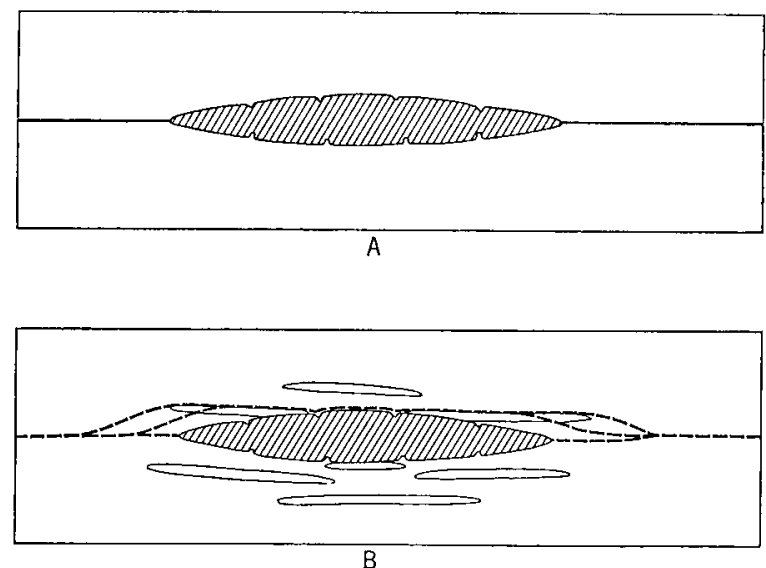

Fig. 43A, B. Diagrams providing an explanation for the concealment in the matrix of some lateral appendages of a compressed plant fossil following exposure of the compression by splitting.

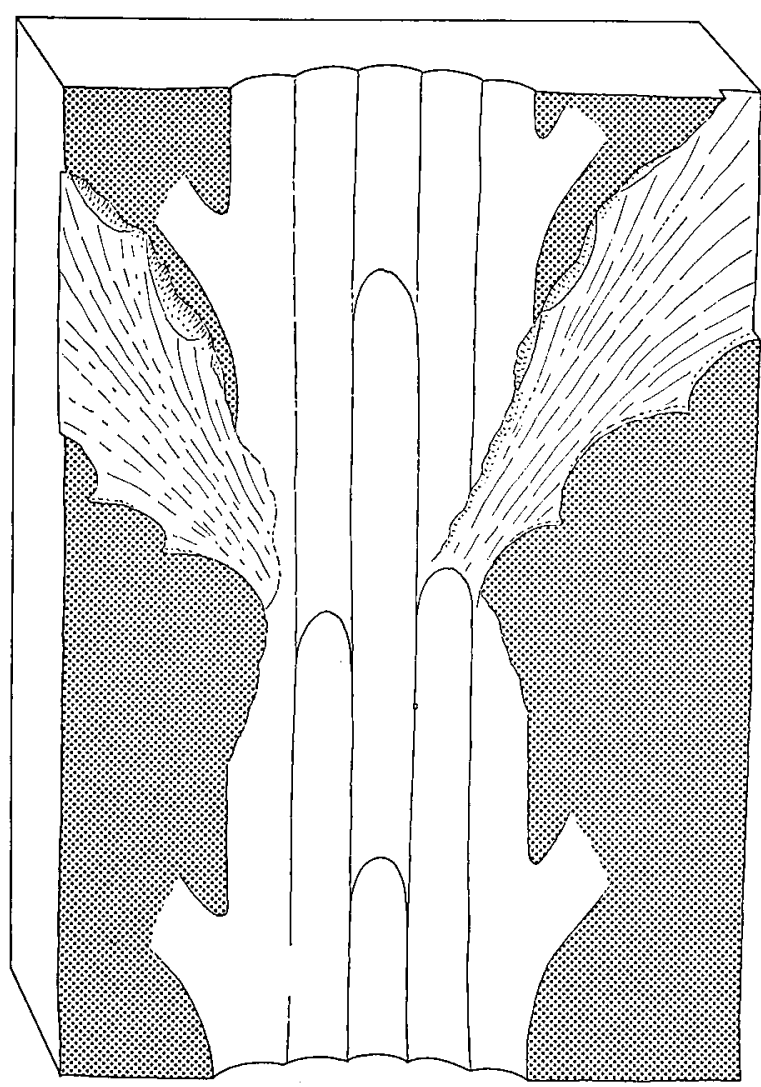

Fig. 44. Diagram illustrating the appearance of the main axis of a lateral branch system of Archaeopteris following removal of the carbonaceous film of a compression. Cf Fig. 37. Further explanation in the text. in our collection exhibit appendages intermediate in morphology between typical vegetative leaves and typical fertile appendages.

Surface features of the main axis-In the impression of almost every specimen of $A$. macilenta, there is a pattern of small depressions which shows up best when observed dry with unilateral illumination (Fig. 30; if the depressions appear as mounds, observe after rotation through $180^{\circ}$ compare with approximately the same region, lower part of Fig. 28, photographed under water). Observations of the outer regions of the structurally preserved axis (375-II) reveal small masses of thick-walled cells, apparently sclereids, which I believe are represented by these depressions.

MAJOR MORPHOLOGICAL CONCLUSIONS-The main axes of lateral branch systems of Archaeopteris are characterized by a helical arrangement of leaves and lateral branches both of which were produced in the same ontogenetic spiral. The lateral branches, nevertheless, are arranged distichously, but may vary from nearly opposite

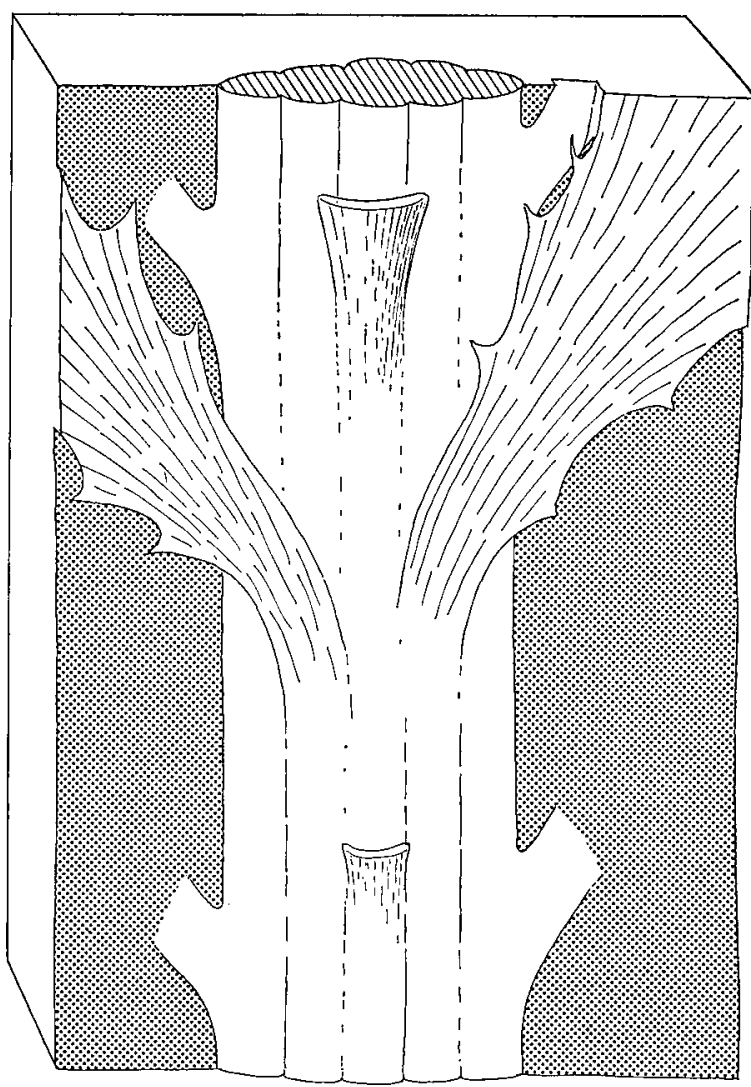

Fig. 45. Diagram illustrating the appearance of the main axis of a lateral branch system of Archaeopteris prior to removal of the carbonaceous film of a compression. $\mathrm{Cf}$ Fig. 36. Further explanation in the text. 
to alternate. Leaf blades diverge from long, decurrent leaf bases that essentially ensheath the axes that bear them. The leaves along the main axis occur in 5-9 orthostichies. There is a greater density of probably smaller leaves on the adaxial side compared with a lower density of probably larger leaves on the abaxial side. In $A$. macilenta leaves of the main axis are larger than those of the lateral axes. On the lateral axes the leaves are arranged in opposite to sub-opposite pairs, apparently in four ranlis (i.e., decussately). There is no apparent difference in the arrangement of appendages on the main axis in vegetative and fertile regions of branch systems, nor is there any observed difference in the arrangement of vegetative leaves and fertile appendages on lateral axes. Many of these conclusions are embodied in two restorations (Fig. 54, 55).

The Restorations-The two restorations, one of a segment of the main axis of a lateral branch system bearing part of a leafy lateral axis (Fig. 54), and the other of a complete vegetative branch system attached to a larger axis (Fig. 55), are based almost entirely on evidence presented in this study. Some of this, however, corroborates evidence reported earlier by myself and others.

The segment of the main axis illustrated in Fig. 54 is shown as if the leaves had abscised, although there is no direct evidence of leaf abscission prior to shedding of the branch systems. If the branch systems continued to develop over several years, it is certainly possible that the old, basal leaves might have abscised, just as do those of similar lateral branch systems in conifers. We do not, of course, know anything about the rate of development of Archaeopteris lateral branch systems, nor do we know that they persisted on the tree for more than one growing season. However, the fact, that fossils consisting of a lateral branch system attached to a larger axis are so rare, and the lateral branch systems so common, suggests strongly that the branch systems were shed as units. Furthermore, the presence of leaves on the basal parts of very large lateral branch systems (see Nathorst, 1902; Johnson, 1911) and even on axes bearing the branch systems (Beck, 1960b, 1962), suggests that the leaves might indeed have been long persistent. This restoration should not, therefore, be taken to mean that the leaves were necessarily of short duration on the axis. It has been drawn as if lacking leaves simply to emphasize the helical arrangement of leaves and branches and the ensheathment of the axis in leaf bases. Furthermore, the number of leaf orthostichies on the main axis and the sub-opposite and decussate arrangement of leaves on the lateral axis might not have been consistent patterns throughout the plant, or even throughout a particular branch system. As has been emphasized elsewhere in this paper, it is probable that the phyllotaxis was highly variable.
The restoration of the complete vegetative branch system (Fig. 55) has been drawn with great care. Relative distances between branches and leaves and their arrangement in orthostichies and parastichies are based directly on specimens $375-\mathrm{G}$ and $375-\mathrm{Y}$. The variation in size of leaves on the main and lateral axes is based largely on $375-\mathrm{Y}$, their morphology on specimens $375-\mathrm{G}$ and 375-MM, and their arrangement on 375-MM. Evidence for variation in leaf size from basal to apical regions of the branch system on both main and lateral axes comes from many specimens in my collection and is circumstantial. The reduction in leaf size toward the tips of lateral axes is based on evidence from a specimen of A rchaeopteris latifolia in my collection, not illustrated in this paper. Evidence for the attachment of the lateral branch system to a larger axis and its subtention by a leaf is presented in earlier papers (Beck, 1960b, 1962). The length of the branch system is arbitrary as is the length of the basal part below the level of the first branches. It is probable that the basal region was usually longer than depicted here.

These restorations should supersede one previously published by me (Beck, 1962, Fig. 1) which is hereby shown to be an incomplete and thus inaccurate representation of a lateral branch system.

Discussion-This study corroborates, in large part, the conclusions of Carluccio et al. (1966) on internal structure of the Archaeopteris lateral branch system. The analysis of external morphology has made it clear that the leaves of the main axis are, indeed, as suggested by anatomy, helically arranged in the two, possibly three, different species considered. We may now be certain, furthermore, that the illustrations and descriptions of opposite or sub-opposite 'rachial pinnules' by many workers simply do not reflect the total morphology of the axes, and we understand why they do not.

The conclusions of this study do not entirely agree with the view of Carluccio et al. (1966) concerning the structure and leaf arrangement of the lateral branches ('pinnae'). They illustrate a 'pinna' axis of Archaeopteris macilenta as having a radially symmetrical primary xylem cylinder characterized by seven radiating ribs from each of which leaf traces diverge alternately, whereas my compression specimens seem to show that the leaves are arranged on the lateral axes in essentially decussate manner. Of course, as noted previously, if leaves were sub-opposite and decussate (or alternate in four ranks), one could interpret them as helically arranged in a $1 / 2$ phyllotaxis. Support for the sub-opposite and decussate arrangement comes not only from this study but also (at least indirectly) from the work of Andrews, Phillips, and Radforth (1965) who describe material of Archaeopteris fissilis. Their restorations 
show both vegetative and fertile 'pinnules' as if sub-oppositely arranged in two ranks. As in the specimen in my Fig. 41 the appendages that would, I believe, be on the upper and lower sides of the axis are not visible because they are contained in the matrix of part and counterpart. In my specimen their presence, at least on one side, was indicated by the leaf base scars on the im- pression of the axis. A four-ranked arrangement of appendages on the lateral axes would be consistent with the four-ribbed configuration of the stele of this axis in its base. Although I have previously suggested (Beck, 1970b) that the structurally preserved axis illustrated by Carluccio et al. (1966, Fig. 1) might represent the apical region of the main axis of a branch system, I

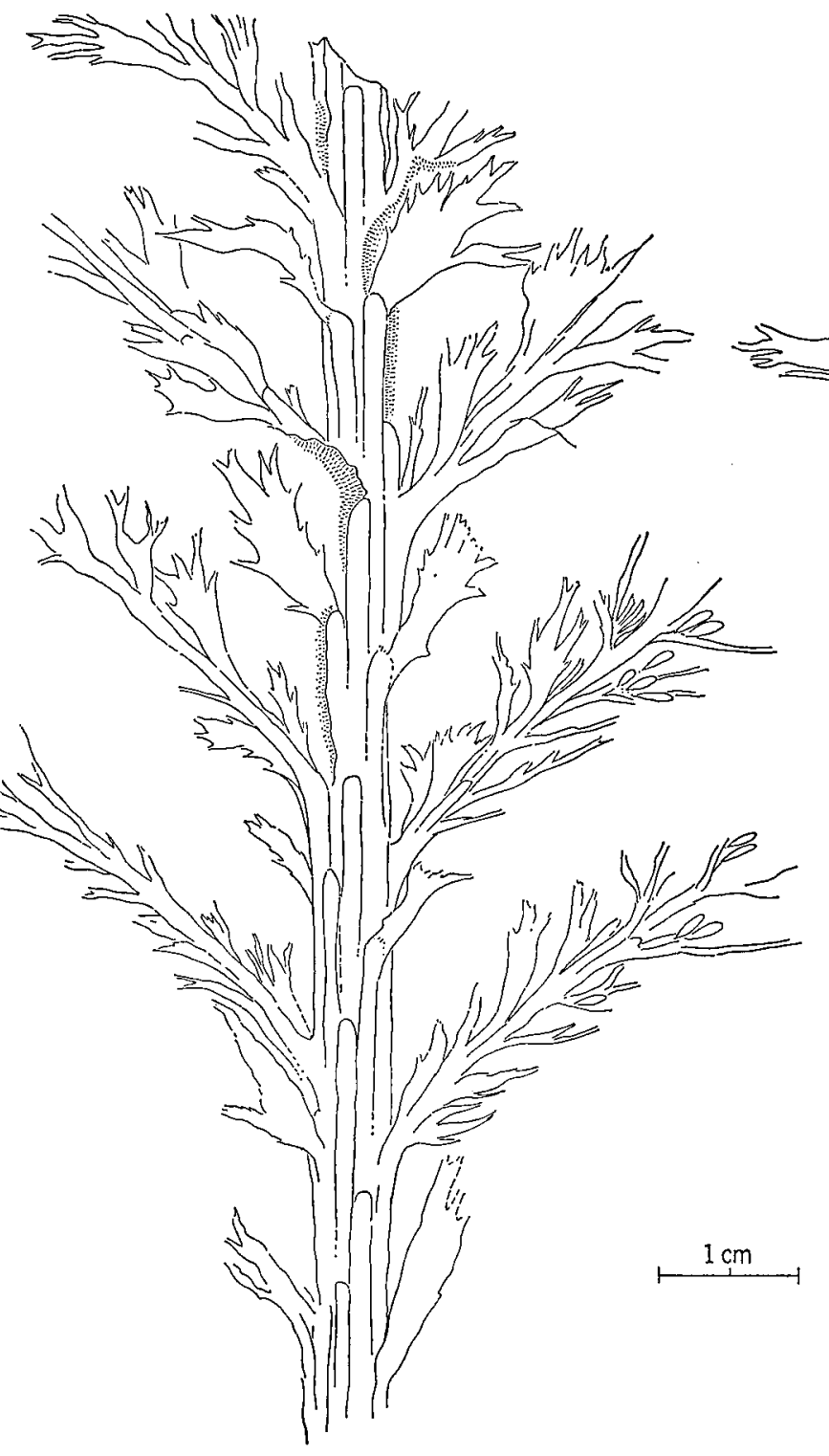

A

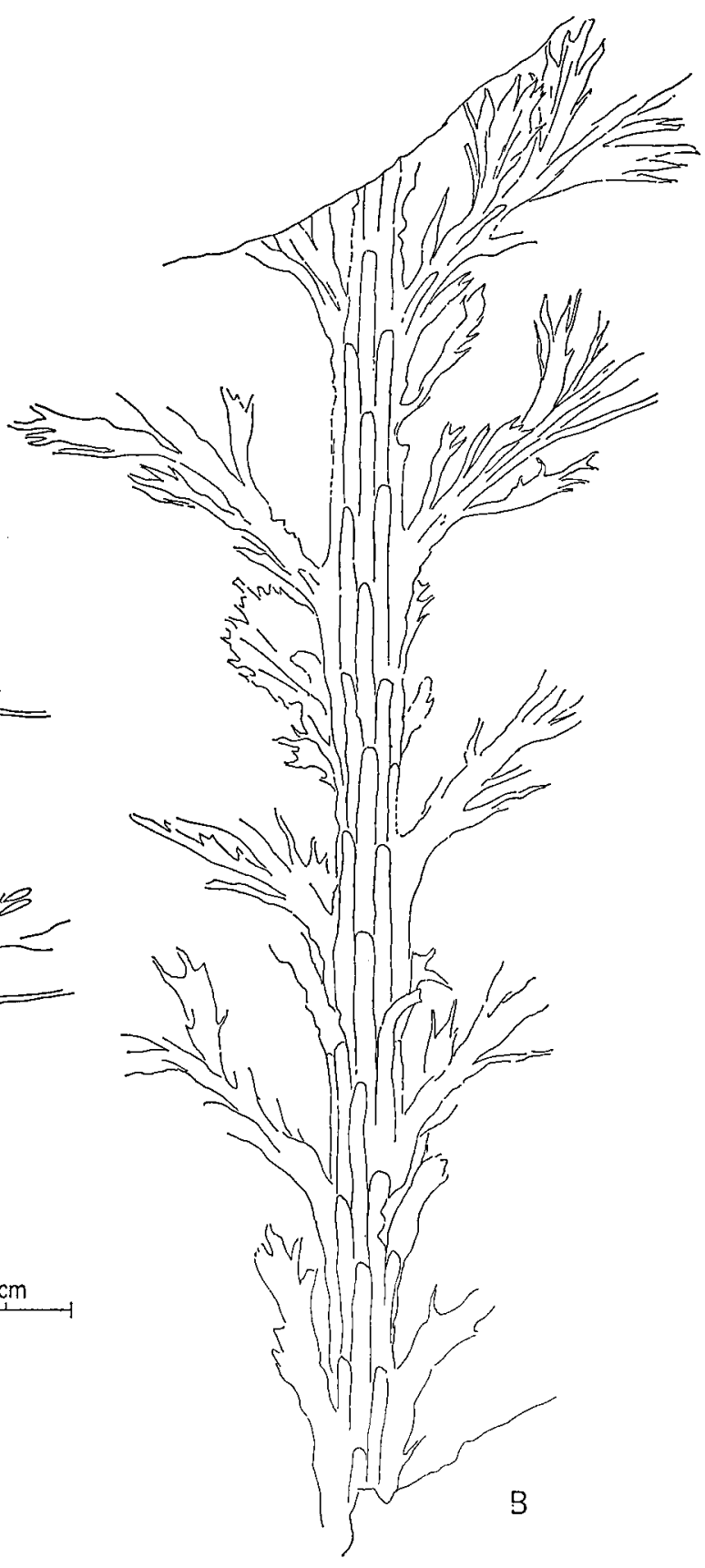

Fig. 46A, B. Archaeopteris macilenta. Camera lucida drawings of part and counterpart, illustrating the leaf base pattern, variation in the pattern on the two sides of the axis, and the positional relationship of leaves and branches. Cf Fig. 28,29 . Detailed discussion in the text. 375-Y. 
readily admit now, that it could represent a lateral branch, although its structure is inconsistent with the external morphology that I have observed. There is good reason to suspect that the number of stelar ribs and the phyllotaxis changed from one level to another along the main axis of the branch sustem; so quite possibly the internal structure, phyllotaxis and, as previously suggested, leaf size, of different lateral axes might vary at different levels in the system. Therefore, whereas the branch trace might develop into a multi-ribbed stele in the basal lateral axes, in those nearer the apical region of the branch system the stele might retain the four-ribbed configuration of the trace throughout the lateral axis. Further study is needed, of course, to confirm or refute this suggestion.

Several genera, e.g., Svalbardia Høeg (1942) and Actinoxylon Matten (1968), have been considered to strongly resemble Archaeopteris but, for one reason or another, have been separated from it. In the light of this study, however, I can no longer accept Svalbardia as a valid genus. Some paleobotanists (e.g., Carluccio et al., 1966; Matten, 1968) have rather strongly emphasized the presumed helical, or at least three-dimensional, arrangement of lateral branches. It is especially interesting, however, that $\mathrm{H} \emptyset \mathrm{eg}$ mentions the possibility of a helical arrangement of branches only in the specific (not generic) diagnosis, as follows: "branches (probably) spiral, with a tendency to arrangement in opposite pairs." In his description he emphasizes the opposite arrangement, stating: "In many cases the branches are approximately opposite. It is somewhat uncertain whether there have been more than two branches at each node; sometimes there are markings indicating that there may have been three or four, but the observations are not reliable." In another place he states: "the lateral branches are not arranged in one plane"; and further: "Although it sometimes looks as if such branches had been placed exactly at a right angle to those which are now found in the bedding plane, it is fairly certain that this was not always the case." This conclusion of orientation of branches in planes alternating at right angles is based on occasional scar-like depressions on the main axis which Høeg interpreted to represent points of entry of vascular tissue into the bases of lateral branches oriented in a plane at $90^{\circ}$ to the surface of the specimen. In the light of the present study, it seems more likely that these scars represent the positions of leaves on the back side of the axis.

Clearly, Høeg's emphasis is on sub-opposite branching with even a suggestion of decussate arrangement, but evidence for the latter is unconvincing. Never is it stated in the description that branches are helically arranged, but it is noted (p. 71,72) that "there is often a considerable vertical distance between the branches belonging to one pair (italics mine), and in several cases they could hardly be considered as being opposite or sub-opposite." The use of helical arrangement of branches as a generic character is, therefore, clearly unjustified. Apparently, branching in Høeg's specimens is sub-opposite to alternate in one plane. This study makes it clear that this type of alternate branching is characteristic of some specimens of Archaeopteris.

The similarities between Svalbardia and $A r-$ chaeopteris are thus remarkable. In fact, Høeg,

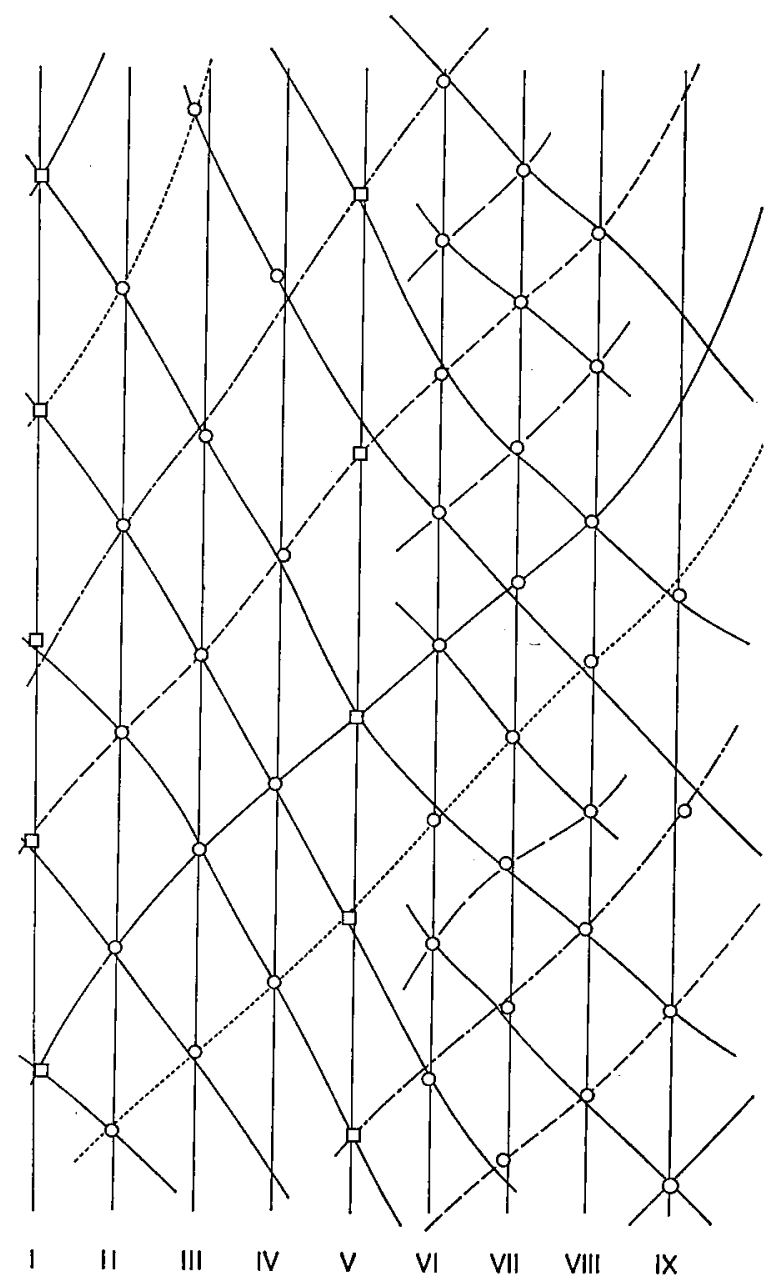

Fig. 47. Diagram of the entire surface of the main axis of specimen 375-Y, showing the pattern of lateral appendages. Based on Fig. 46A, B. Squares represent points of attachment to the surface of branches; circles represent points of attachment of leaf blades. Vertical lines, I-IX, represent 9 orthostichies of appendages. Note three leaf orthostichies on the left between the 2 branch orthostichies, representing those on one side of the axis (shown in Fig. $46 \mathrm{~A}$ ); and 4 leaf orthostichies on the right, representing those on the reverse side of the axis (shown in Fig. 46B). Diagonal lines indicate two sets of contact parastichies. Note discontinuous parastichies on the right and the greater leaf density on that side than on the other. Further explanation in the text. 
himself said (1942, p. 80): "some of our specimens bear such a resemblance to [Archaeopteris fissilis] that they can scarcely be distinguished from it ...." He states further: "the resemblance also goes very far in the matter of the fructifications, which in their general morphology are identical with those of all species of Archaeopteris."

Høeg considers the most important generic character of Svalbardia to be the absence of "a composite leaf regularly expanded in one plane." A similar type of filiform, highly dissected appendage which he describes for Svalbardia, however, characterizes Archaeopteris fissilis (Schmalhausen, 1894; Nathorst, 1904; Andrews et al., 1965). If, therefore, one accepts the view that the branching pattern of Svalbardia does not differ from that of Archaeopteris, there seems to be no basis for generic distinction. Consequently, Svalbardia polymorpha Høeg (1942) should be considered a synonym of Archaeopteris fissilis Schmalhausen (1894).

I agree with the suggestion of Carluccio et al. (1966) that Svalbardia boyi Kräusel and Weyland (1960) is probably an Archaeopteris. Svalbardia avelinesiana Stockmans (1968) presents a somewhat more complex picture and appears to be comprised of specimens that might be assigned to several different genera including Archaeopteris (Stockmans' Pl. VI, Fig. 3, 3a), Rhacophyton (Pl. II, Fig. 6, 6a), and Pseudosporochnus (Pl. II, Fig. 2-4). I have not seen the work of Petrosian and Radczenko who have described Svalbardia osmanica from the U.S.S.R. (see Andrews, in Boureau, 1970, p. 24).

Since the sub-opposite and decussate arrangement of leaves is no longer a valid basis for generic separation, Actinoxylon Matten (1968) seems now to be distinguishable from Archaeopteris only by the helical arrangement of lateral branches.

A particularly interesting problem that has arisen in this study is the nature of the phyllotaxis. Since leaf and branch traces develop along the same ontogenetic spiral, both leaves and branches must be included in a determination of 'phyllotaxis'. In specimen 375-II there seems, on this basis, to be a phyllotactic fraction of $2 / 9$ and parastichy numbers of $5+9$. This is most surprising since the number 9 does not occur in either the primary or secondary series of Fibonacci numbers. Furthermore, in such a plant the limiting angle of divergence would be less than $90^{\circ}$, an infrequent condition among living plants. (Where phyllotaxis is bijugate, however, the angle of divergence may be as small as $70^{\circ}$ ). In plants that are characterized by the secondary series of Fibonacci numbers the limiting angle is about $99^{\circ}$. Theoretically, the limiting angle is usually not much less than $90^{\circ}$ because of the limitations of space. Whether this angle is controlled primarily by physical space, i.e., by the size of the primordia in relation to size of the apical meristem, or whether it is more closely related to the size of 'fields' of inhibitory chemical substances produced by the young primordia is not known. If physical space were not limiting and chemical inhibitory fields were small, then the primordia might very well de-relop closer together than is typical in extant plants. It should be remembered, of course, that the phyllotactic fraction of $2 / 9$ in Archaeopteris is obtained only if traces develop in succession from every other one of the nine ribs of the stele. The anatomical study suggests that this is true. The morphological study, however, seems to indicate that some of the leaf primordia, represented by these traces, abort. Consequently, the density of mature leaves on the main axis is less than would be indicated by this fraction, and this phyllotactic fraction could not be derived from study of external morphology. As has been noted, however, the abortion takes place on one side of the axis only and cannot, therefore, be logically explained as a means of reducing crowding in the apical meristem. It must, however, be a genetically controlled phenomenon and thus, must result in a morphology of some adaptive value, a point to which I shall later return.

Specimens with seven orthostichies would, given an alternating trace origin involving all of the seven ribs of the stele, have a phyllotaxis of $2 / 7$, a fraction of the secondary Fibonacci series. If, as also suggested by this study, there are axes with steles consisting of 11 ribs, it seems reasonable to predict in these a phyllotaxis of $3 / 11$. In such a system, traces would originate in succession along the ontogenetic spiral from every third rib. Carluccio et al. (1966) describe steles in their material with eight and ten ribs, and indirect evidence for eight is presented herein. Siderella scotti Read (1936), probably the structure of the main axis of an Archaeopteris lateral branch system (Carluccio et al., 1966), is also characterized by a 10-ribbed stele. An axis with an 8-ribbed stele would likely have a $3 / 8$ phyllotaxis. This would require trace divergence from every third rib in succession, i.e., two ribs would intervene between those from which successive traces diverged. Nevertheless, Carluccio et al. state that traces originate in their material from alternate ribs. If true in a stelar system with an even number of ribs, only half would comprise the sites of trace origin, a rather unlikely condition. In those axes with 10-ribbed steles it seems quite probable that phyllotaxis was bijugate. In a recent study Namboodiri and Beck (1968a) show that in a specimen of each of three different bijugate conifers, Larix laricina, Cephalotaxus drupacea, and Torreya californica, the stele is characterized by ten sympodia; and a second bijugate specimen of Cephalotaxus drupacea exhibits a stele of 16 sympodia. It should be noted that these numbers (10 and 16) are double the numbers 5 and 8 of the Fibonacci series. In each case the limiting angle is about $70^{\circ}$, one half the 
angle expected if there had been only one ontogenetic spiral. Where bijugate phyllotaxis characterizes an axis with 10 sympodia, each of the two parallel ontogenetic spirals considered separately, would be characterized by leaves arranged in a $2 / 5$ phyllotaxis. In such a bijugate system traces would diverge from adjacent ribs at almost the same level, with two ribs intervening between these and the next two adjacent ribs from which traces would diverge in the two parallel ontogenetic spirals. Interestingly, trace divergence in Siderella seems to conform exactly to this pattern (see Carluccio et al., 1966, Fig. 2).

There is evidence, therefore, of considerable variation in phyllotaxis in Archaeopteris macilenta. This is reflected in the variation in morphology of the primary vascular system, i.e., in the number of ribs as well as in the variation in the number of rows of leaves as indicated in the impressions. It seems very likely that such variation may even characterize individual specimens, different phyllotaxis, and correlated anatomy, occurring in different regions of a branch system or even in different parts of the main axis.

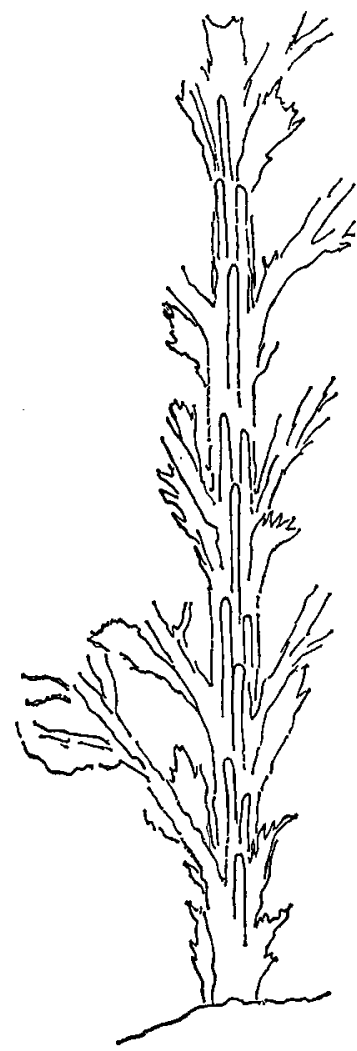

A

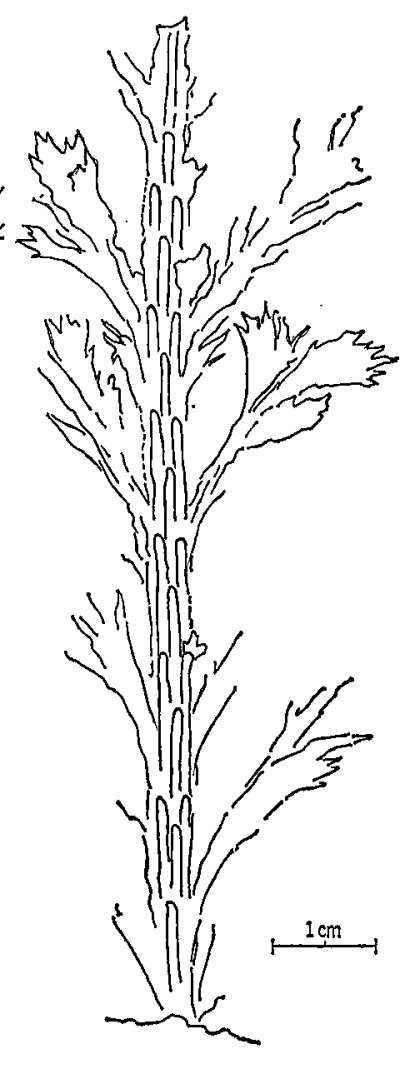

B
Fig. 48A, B. Archaeopteris macilenta. Camera lucida drawings of part and counterpart, illustrating the leaf base pattern on a main axis of a lateral branch system characterized by 3 leaf orthostichies on each side. Note also, variation in leaf density on the two sides.
Such variation in phyllotaxis and internal structure is well known among living plants both within species, within different regions of individual plants, and within individual axes. As noted above, we have shown that within one species, Cephalotaxus drupacea, a specimen of one plant has a stele of 10 sympodia, whereas another specimen has a stele of 16 sympodia. Although both are bijugate, the phyllotactic fraction of $2 / 5$ characterizes the first and $3 / 8$, the second, if one considers individual ontogenetic spirals (Namboodiri and Beck, 1968a). We also observed one bijugate specimen of Larix laricina with 10 sympodia and another specimen with 13 sympodia and a phyllotaxis of 5/13. We have recorded, further, in the same study different specimens of Sequoia sempervirens, Sequoiadendron giganteum, and Cunninghamia lanceolata with varying numbers of sympodia and correspondingly varying phyllotactic fractions. Most significantly, Barthelmess (1935), Camefort (1956), and Kumari (1963) have provided examples of change in phyllotaxis along individual axes in several conifers and have demonstrated the correlation between such phyllotactic changes and changes in the architecture of the primary vascular system. [For additional examples and more detailed discussions of changes in phyllotaxis, see Richards (1951) and Snow (1955).]

The lateral branch systems of Archaeopteris are remarkably similar in morphology to those of many conifers. Consequently, it would not be surprising to find, in the terminal parts of the main axis of Archaeopteris branch systems, details of phyllotaxis and anatomy very similar to those of the lateral axes of the systems nor, as suggested above, to find considerable variation between basal and more apical parts of the main axis. It seems most unlikely, therefore, that such morphological and anatomical variation in isolated fossils would have any taxonomic significance. There is, then, apparently no basis in the form of the stele or the pattern of trace divergence in the main axis for maintaining Siderella as a genus distinct from Archaeopteris. The possibility that leaves were arranged in one plane on the lateral axes (Carluccio et al., 1966), however, prevents me from placing it in synonymy at present, although such a morphological difference might merit no more than specific status.

One of the most interesting aspects of the morphology of the Archaeopteris lateral branch system is the occurrence of leaves and branches in the same ontogenetic spiral. This would seem to have some bearing on the problem of the homology of leaves and shoots. Cutter (1957) describes the occurrence of both flowers and vegetative buds in leaf positions in Nymphaea alba and notes $(1957,1958)$ their serial homology. In view of the paleobotanical evidence which support the homology of leaves and branch or shoot systems (Beck, 1970a), it seems reasonable to 


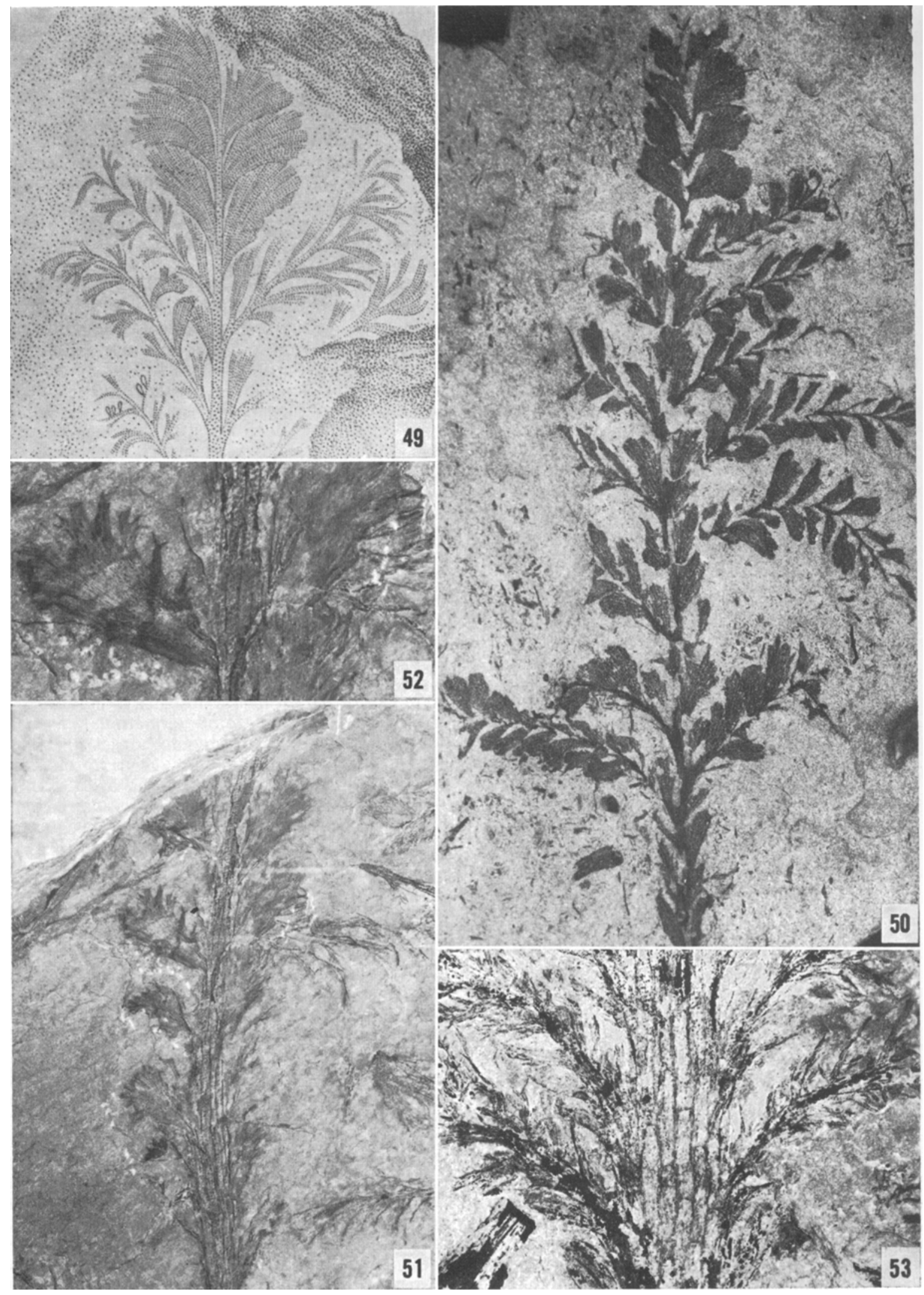




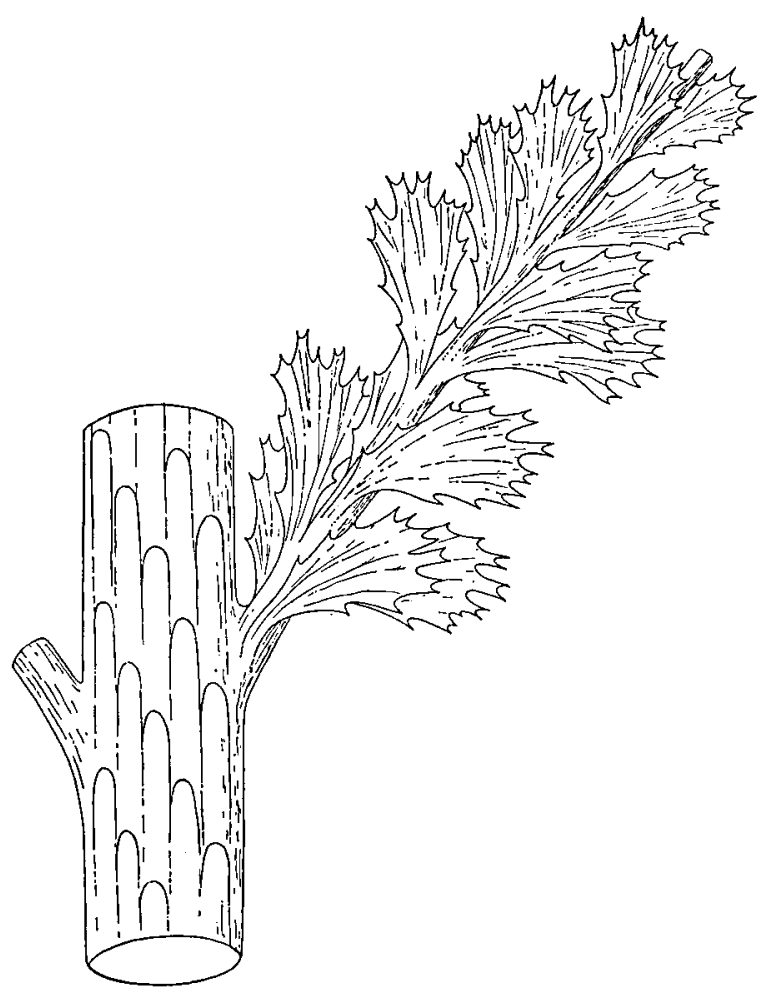

Fig. 54. Archaeopteris macilenta. Restoration of part of a lateral branch system, showing a segment of the main axis ensheathed in leaf bases as if its leaves had abscised, and a part of a lateral branch bearing leaves.

accept this type of evidence as additional support for that idea.

Cutter (1958) cites examples of the occurrence of shoots in leaf positions in several pteridophytes and has demonstrated (1956) that buds can be induced to develop from leaf primordia in Dryopteris aristata by appropriate experimental treatments. Because of the potential for development of incipient primordia into either leaves or shoots in a primitive angiosperm such as Nymphaea and in several pteridophytes, Cutter (1958) raises the question of whether this developmental potentiality might be phylogenetically ancient. The morphology of the main axis of the lateral branch systems of Archaeopteris provides positive support for this idea.

Another fascinating feature of the Archaecpteris branch system is the occurrence of leaves in greater density on one side of the main axis than on the other. Since this seems to be a consistent feature, it must have had some adaptive value. The restoration (Fig. 55) may provide a clue. It seems very probable that some of the leaves on the lower side of the main axis, if produced in equal numbers on both sides, would have been shaded by those above. Fewer, larger leaves on the lower side, presumably, became arranged in such a manner as to obtain sufficient light for photosynthesis. Those which were inefficient in photosynthesis might then have been eliminated through early abortion of leaf primordia. This would have adaptive value and be selected for because it would be a means of energy conservation within the plant. It is on this basis that I suggest that the adaxial side of the branch systems is the one with the greatest density of leaves.

Several workers (Carluccio et al., 1966; Beck and Bailey, 1967; Matten, 1968; Beck, 1970a) have suggested that the branch systems of Archaeopteris might represent an intermediate stage in the evolution of the compound leaf. Although in the past this view, based on the planation of the Archaeopteris lateral branch systems, was a reasonable one, comparison of these with the frond-like branch systems of some extant conifers has provided me with a basis for some skepticism as indicated by my recent suggestion that "a proposed intermediate form such as the Archaeopteris 'frond' might have been no more evolutionarily intermediate between a primitive lateral branch system and a compound leaf than are the lateral branch systems ('fronds') of Taxodium or Metasequoia" (Beck, 1970a). The evidence provided herein strongly supports and makes more meaningful that viewpoint.

Finally, I want to consider the phylogenetic implications of our new understanding of the morphology of the lateral branch systems of Archaeopteris. When it was first discovered that Archaeopteris represented the foliage of plants with the stem structure of Callixylon (Beck, $1960 \mathrm{a}, \mathrm{b})$, I suggested that it might represent a group of pteridophytic progymnosperms from which gymnosperms evolved. Subsequently, studies of the 'frond' by Carluccio et al. (1956) and of the primary vascular system and secondary wood (Beck, 1970a) have provided evidence that this plant was most closely related to the coniferophytic gymnosperms. The present work considerably strengthens this view. The helical arrangement of leaves with decurrent leaf bases nearly completely ensheathing the axes on which they were borne results in a remarkable resemblance of these lateral branch systems to those of

Fig. 49-53.-Fig. 49. Archaeopteris macilenta, showing leaves on apical part of main axis. 375-LL. $\times 1$. -Fig. 50. Archaeopteris halliana. Holotype. From C. A. Arnold, 1939. Used with permission. $\times 1 .-$ Fig. 51, 52. Archaeopteris macilenta.-Fig. 51. Probable base of main axis of lateral branch system. 375-M. $\times 1$. -Fig. 52. Detail of Fig. 51 . $\times 2.2$. -Fig. 53. Archaeopteris macilenta. Main axis, illustrating close vertical proximity of leaves in the 4 leaf orthostichies. Note that vertical distance between branches equals that between leaves. Cf Fig. 28. 375-Q. $\times 2.2$. 


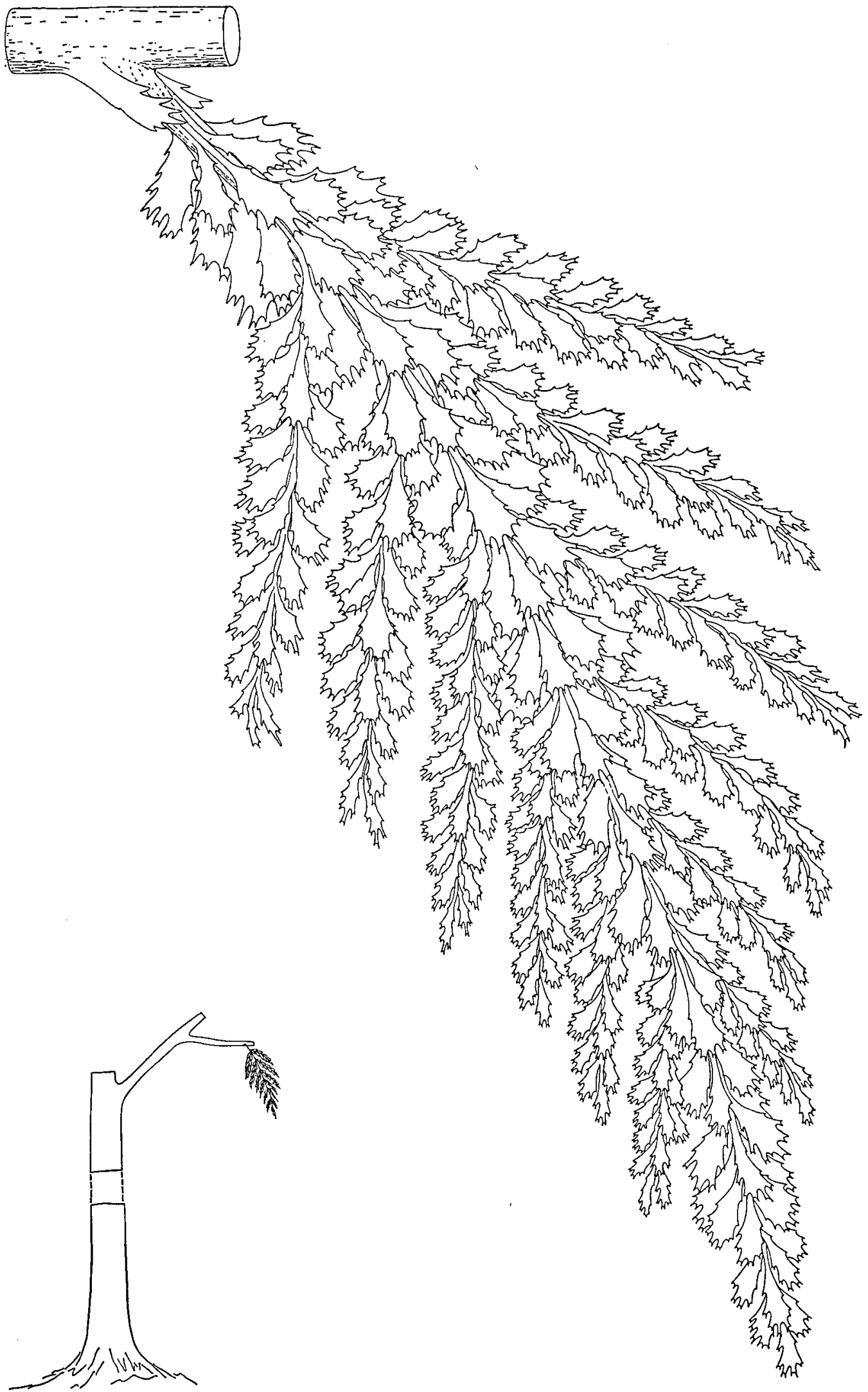

Fig. 55. Archaeopteris macilenta. Restoration of a lateral branch system. 

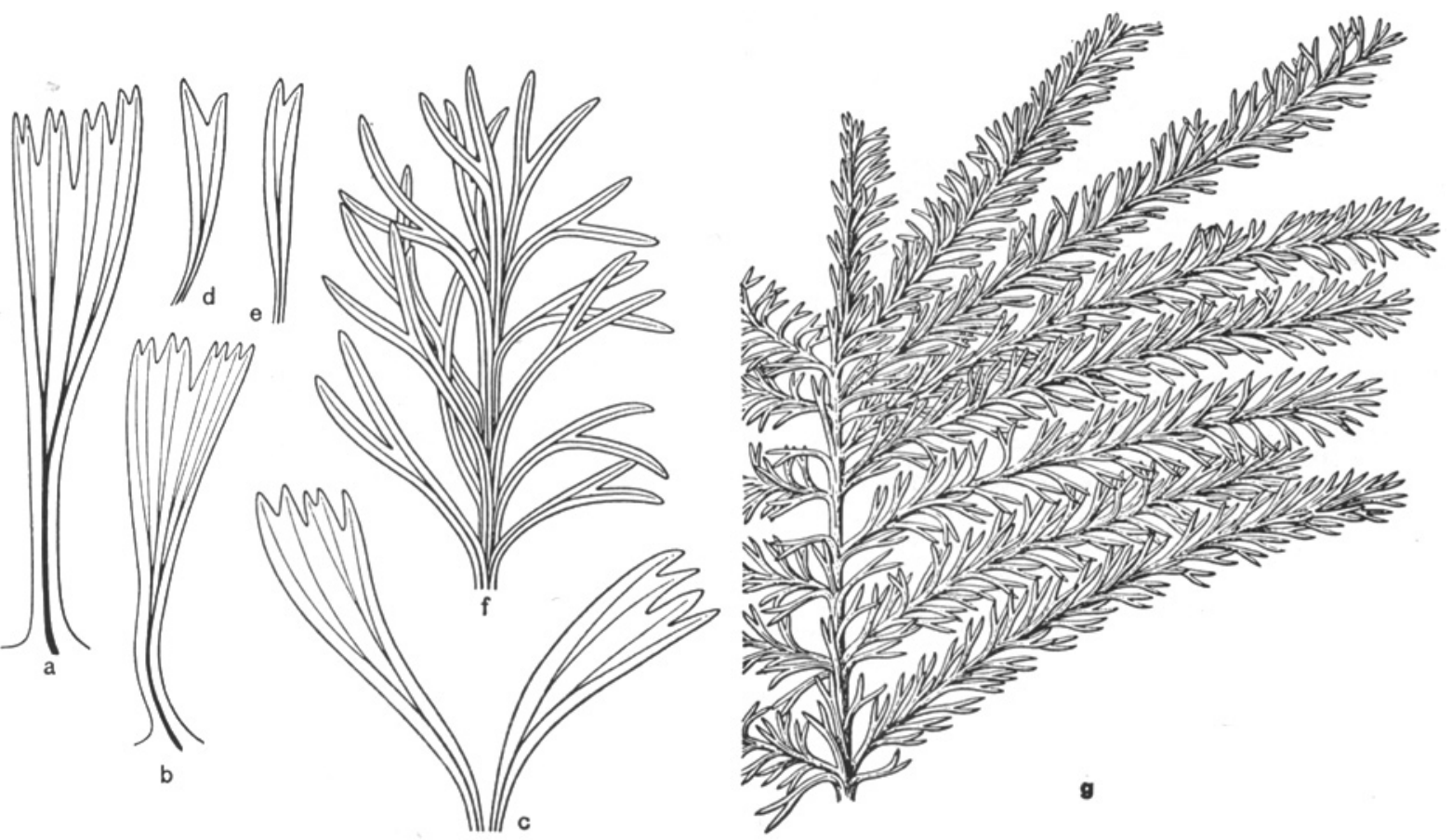

Fig. 56a-g. From R. Florin, 1951. Used with permission.-Fig. 56a-e. Buriadia heterophylla. Leaves, showing variation in morphology.-Fig. 56f, g. Carpenteria frondosa.-Fig. 56f. Details of leaf form and arrangement at the tip of a lateral branch.-Fig. 56g. Restoration of a branch system.

many conifers. Were the leaves awl-shaped or needle-like, rather than flabelliform, a compression of a branch system would simulate a conifer almost exactly. Significantly, there were among primitive, Lower Permian conifers, several taxa, e.g., Buriadia heterophylla and Carpentieria frondosa (see Florin, 1951), that closely resembled Archaeopteris, even in details of leaf morphology. Compare the restoration of Carpentieria (Fig. $56 \mathrm{~g})$ with that of Archaeopteris and note details of leaf morphology and arrangement (Fig. 56f). Buriadia also was similar in branching pattern and even more similar to Archaeopteris in leaf morphology (Fig. 56a-e).

By this comparison I do not mean to suggest that Archaeopteris was an immediate ancestor of these Permian conifers. I do suggest, however, the possibility that they represent a single evolutionary line. Intermediate forms might be represented by some specimens of poorly understood Mississippian compression genera such as $R h a-$ copteris, Sphenopteridium, Rhodea, Adiantites, etc. (see Read, 1955). I suggest, furthermore, that the Cordaitales might very well be a side branch of the main phylogenetic line of the coniferophytic gymnosperms and not, therefore, the immediate precursors of the coniferales. Obviously these ideas need much further testing and suppert with concrete evidence before they can be accepted.

It is now absolutely certain that Archaeopteris is not a fern. Established beliefs are, however remarkably difficult to dispel, even when evidence for an alternative seems overwhelming. In a recent major work Archaeopteris has again been grouped with the ferns (Boureau, 1970) although the remarkable conifer-like secondary wood called Callixylon (see Arnold, 1930, 1931; Beck, 1960b, 1970a), distinctively different from the primary (or secondary?) wood of any fern, has been known to be the wood of this plant since 1960 .

A different and unusual assignment is that of Wagner (1967, in Chapter 6 of Harland et al.) who includes Archaeopteris, but not Callixylon, in the Pteridospermopsida. Barnard (1967), on the other hand, in the same chapter, retains both Archaeopteris and Callixylon in the Progymnospermopsida.

The accumulated evidence suggests persuasively that Archaeopteris should be either considered, with related progymnosperms, as a separate major taxon, or be included in the Coniferophyta:

\section{LITERATURE CITED}

Andrews, H. N., T. L. Phillits, and N. W. Radforth. 1965. Paleobotanical studies in Arctic Canada. I. Archaeopteris from Ellesmere Island. Can. J. Bot. 43: 545-556.

ARnold, C. A. 1930. The genus Callixylon from the Upper Devonian of central and western New York. Pap. Mich. Acad. Sci. 11: 1-50. 
1931. On Callixylon newberryi (Dawson) Elkins et Wieland. Contrib. Mus. Paleontol. Univ. Mich. 3: 207-232.

- 1939. Observations on fossil plants from the Devonian of eastern North America. IV. Plant remains from the Catskill Delta deposits of northern Pennsylvania and southern New York. Contrib. Mus. Paleontol. Univ. Mich. 5: 271-314.

Barnard, D. P. W. 1967. Class Progymnospermopsida Beck 1960. In W. B. Harland et al. [ed.], The fossil record. Chapter 6, Gymnospermophyta. Geol. Soc. Lond., London.

Barthelmess, A. 1935. Über den Zusammenhang zwischen Blattstellung und Stelenbau unterer besonderer Berücksichtigung der Koniferen. Bot. Arch. 37: 207-260.

BECK, C. B. 1960a. Connection between Archaeopteris and Callixylon. Science 131: 1524-1525. 1960b. The identity of Archaeopteris and Callixylon. Brittonia 12: 351-368.

- 1962. Reconstructions of Archaeopteris, and further consideration of its phylogenetic position. Amer. J. Bot. 49: 373-382.

-1. 1967. Eddya sullivanensis, gen. et sp. nov., a plant of gymnospermic morphology from the Upper Devonian of New York. Palaeontographica 121B: 122 .

—_- 1970a. The appearance of gymnospermous structure. Biol. Rev. 45: 379-400.

- - 1970b. Problems of generic delimitation in paleobotany. Proc. N. Amer. Paleontol. Conv., Part C: $173-193$

- — AND R. E. BAILEy. 1967. Plants of the New Albany shale. III. Chapelia campbellii gen. n. Amer. J. Bot. 54: 998-1007.

Boureau, E. 1970. Traité de Paléobotanique. Vol. IV, Part 1. Filicophyta. Masson et Cie, Paris.

Camefort, H. 1956. Etude de la structure du point végétatif et des variations phyllotaxiques chez quelques gymnospermes. Ann. Sci. Nat. Bot., Ser. XI, 17: 1-185.

Carluccio, L. M., F. M. Hueber, and H. P. Banks. 1966. Archaeopteris macilenta, anatomy and morphology of its frond. Amer. J. Bot. 53: 719-730.

Cutrer, E. G. 1956. Experimental and analytical studies of pteridophytes. XXXIII. The experimental induction of buds from leaf primordia in Dryopteris aristata Druce. Ann. Bot. N.S. 20: 143-165.

- 1957. Studies of morphogenesis in the Nymphaeaceae. I. Introduction: Some aspects of the morphology of Nuphar lutea (L.) Sm. and Nymphaea alba L. Phytomorphology 7: 45-56.

- - 1958. Studies of morphogenesis in the Nymphaeaceae. III. Surgical experiments on leaf and bud formation. Phytomorphology 8: 74-95.

Florin, R. 1951. Evolution in cordaites and conifers. Acta Horti Bergiani 15: 285-388.

GEYLER, H. T. 1867. Ueber den Gefässbündelverlauf in den Laubblattregionen der Coniferen. Jahrb. Wiss. Bot. 6: 55-208.
HøEG, O. A. 1942. The Downtonian and Devonian flora of Spitzbergen. Norges Svalb. Ishavs-Unders $\varnothing \mathbf{k}$ 83: 1-228.

Johnson, T. 1911. Is Archaeopteris a pteridosperm? Sci. Proc. Roy. Dublin Soc., N.S. 13: 114-136.

KräUsel, R., AND H. Wextand. 1960. Drei neue Pflanzen aus dem Devon. Palaeontographica 107B: $65-82$.

Kumari, G. K. 1963. The primary vascular system of gymnosperms: a comparative study based on thirty species of twenty-three genera of conifers augmented by data from extinct gymnosperms and progymnosperms. Ph.D. thesis, Univ. Michigan.

Lesquereux, L. 1884. Deseription of the Coal Flora of the Carboniferous Formation in Pennsylvania and throughout the United States, vol. 3. Geol. Surv. Pennsylvania. Harrisburg.

Matten, L. C. 1968. Actinoxylon banksii gen. et sp. nov.: a progymnosperm from the Middle Devonian of New York. Amer. J. Bot. 55: 773-782.

Namboodiri, K. K., AND C. B. Beck. 1968a. A comparative study of the primary vascular system of conifers. I. Genera with helical phyllotaxis. Amer. J. Bot. 55: 447-457.

AND —- 1968b. A comparative study of the primary vascular system of conifers. II. Genera with opposite and whorled phyllotaxis. Amer. J. Bot. 55: $458-463$.

- AND ——. 1968c. A comparative study of the primary vascular system of conifers. III. Stelar evolution in gymnosperms. Amer. J. Bot. 55: 464-472.

NAthorst, A. G. 1902. Zur Oberdevonischen Flora der Bären-Insel. J. Svenska Vetenkaps-Akad. Handl. 36: $1-60$

—__ 1904. Die Oberdevonische Flora des Ellesmere Landes. Rept. Second Norwegian Arctic Exped. (1898-1902). No. 1: 1-22.

Posthumus, O. 1924. On some principles of stelar morphology. Rec. Trav. Bot. Neerl. 24: 111-296.

READ, C. B. 1936. A Devonian flora from Kentucky. J. Paleontol. 10: 215-227.

- - 1955. Flora of the Pocono formation and Price sandstone in parts of Pennsylvania, Maryland, West Virginia, and Virginia: U.S. Geol. Survey Prof. Paper, no. 263: 1-32.

Richards, F. J. 1951. Phyllotaxis: its quantitative expression and relation to growth in the apex. Phil. Trans. Roy. Soc. London 235B: 509-564.

Schmalha USEN, J. 1894. Über Devonische Pflanzen aus den Donetz-Becken Mem. Comité Geol., Leningrad 8: 1-36.

ScotT, D. H. 1923. Studies in Fossil Botany, vol. II, 3rd ed. A. and C. Black, London.

SNow, R. 1955. Problems of phyllotaxis and leaf determination. Endeavour 14: 190-199.

Srockmans, F. 1968. Vegetaux Mesodevoniens recoltes aux confins du massif du Brabant (Belgique). Mem. Inst. Roy. Sci. Nat. Belgique, No. 159: 1-49.

Wagner, R. H. 1967. Class Pteridospermopsida. In W. B. Harland et al. [ed.], The fossil record. Chapter 6, Gymnospermophyta. Geol. Soc. Lond., London. 